よ固 分

び有にヘ一

社な整意・

会現序味一一

至象ざれを社

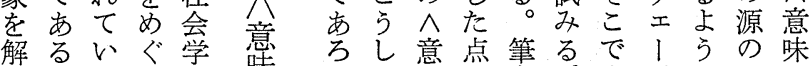

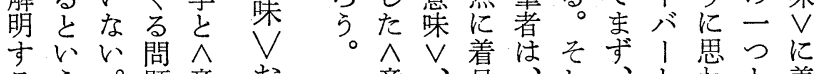
るう。題意お意々目、ししとおと着 社認しは味よ味記しこてへシれし冒

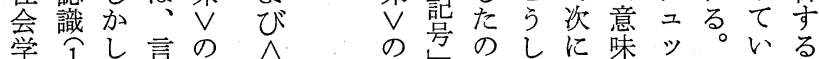

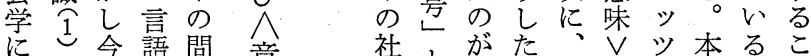

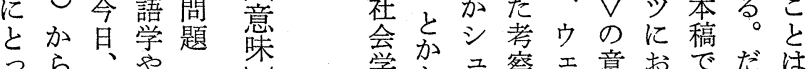

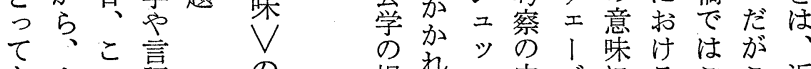
も人の語の視れッ中バにるここ近 、間 $\wedge$ 哲 意角るでか1つへのう年 $\wedge$ に意学味・音あらのい意へしの 意よ味に方意り、てて味意た社 味っ $\vee て か ゙ い$ の成きて

視りわ政 点立 め

范らてい

不社人ま

可会間だ

欠おに充

バさる。熊潮学で 1て 派効おる の ᄂ ᄂ 理こ 解のてて文

社 $\wedge$ 置対 $\wedge$ さ 会意さ論意れ 学味甪揭、つ お学論げにあ

よ派着る。

びに属年り冒い

そ属杂肎るう

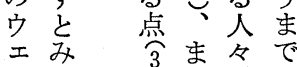

1る 馞がも バこない社な 社㤎㔔わ会こ

会で、らる理の

学き窥筧論こ 方意り、陎主理の、意た社 はV 合と解言のV潮学 、理せし解語視の内の 人解ててを角多に一 間般、シへ広哲を義いつ 意般工意義学検性るの 識そッ味に学討に諾思 そそツ、解の专論論潮 のての付し例る度者と 汃へ与た示。夺にな

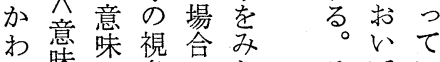
り、整角のたてい 杯発詨よ意で、卡際意そ。 欠生る 的 $\vee$ 筆意そ と的視日理 $匚$ 者 $V$ て るな側角常解 ば的論意の と面方理に । 意味思 問向解おの昧へ潮 う䦗\&のけ、俞は 点題検構る意 に容 $\mathrm{M}$ でよ討造、味 着や $\mathrm{M}$ 種でる解意概昌之方

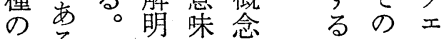

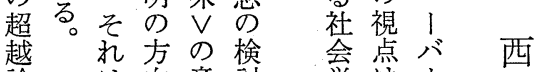
論は向意討学は! 的主を味なのかや アに析内、立なA 原

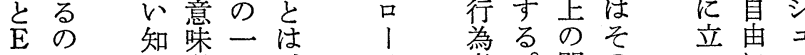
・はる学っ、奢。問の立にッ フ学派の近をそ題若て用ツ

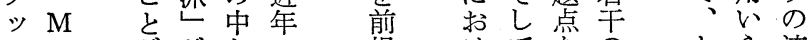

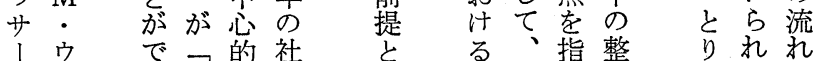

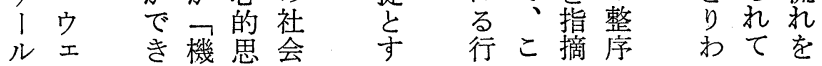

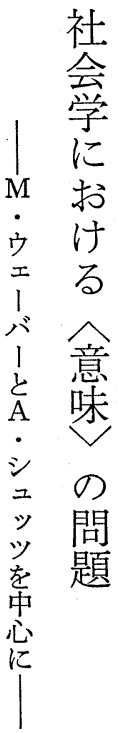


会記状扱ボた味あ一てメはらめのバがミは めのの

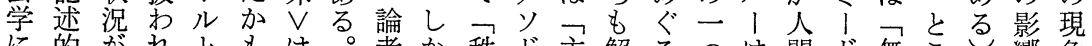

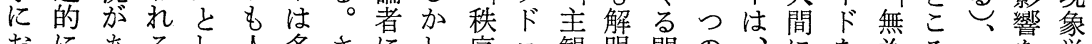
おに票るし人多さにし、序口観明問の、に盖為るさを学

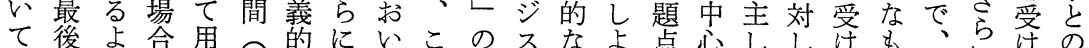

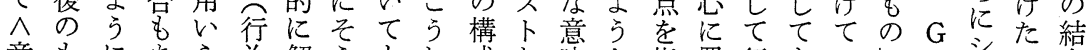
意もにあら為解うもし成た味々指置行もシし・ シ

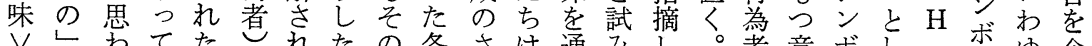

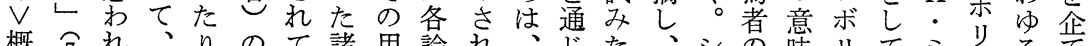

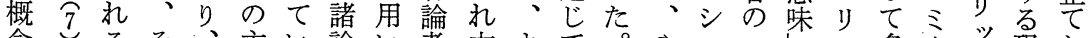

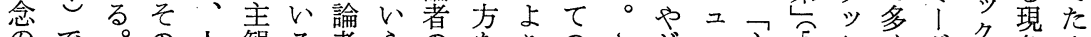
ので。の人観る者らの常りりのさがッ主 検あ 充間性場の檥探ラ社らてッ観を相をは相学・

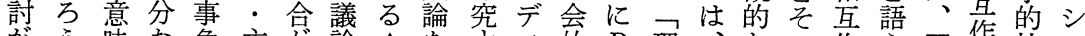

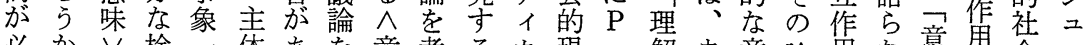
必公 $V$ 検一体あを意考る力現: 解ウ意論角な意用会ッ

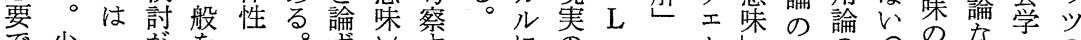

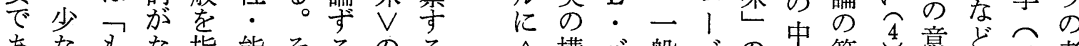

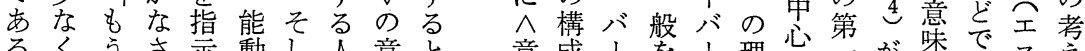

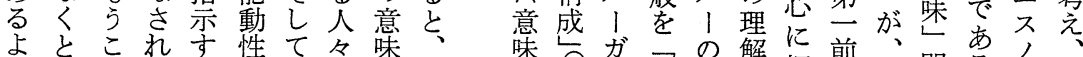

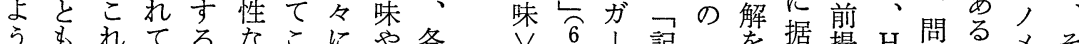
に筆以、簡先の視論

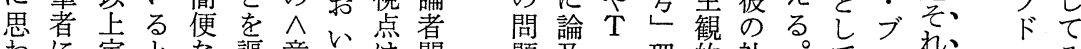

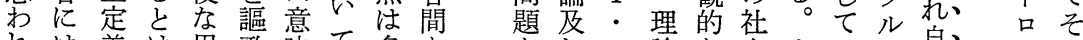

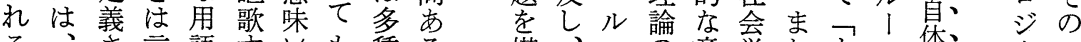
る、さ言語す、も種る 媒、ッの意学たも市体、シ

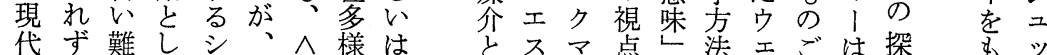

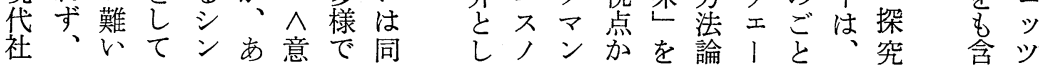

発さま导論立用で味学、味扱心えこの会 信れりし、意 $、 W$ 的でと諸会こ

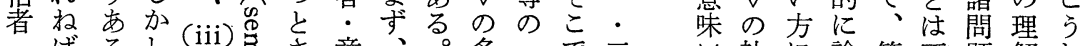

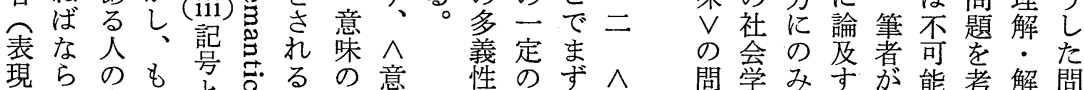
現ら の 者な意ち記流す者味を知、意題の置る関で察明題

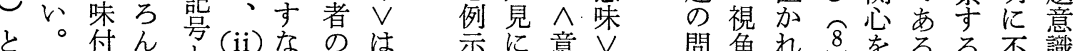
と。付ん方 (ii)なのは示に意 $、$ 問角れ 8 をるる不識 受こ与 $\wedge$ の記わ間記し基味の 題・る。抱か。可の 信のと意関号ちに号、基、視性方。そくらた不

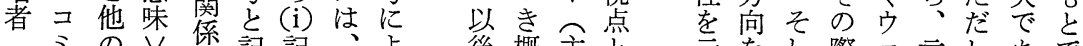
解三人

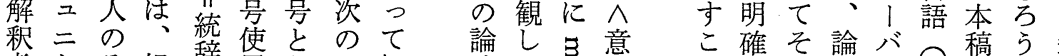

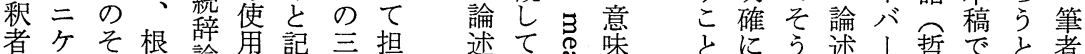

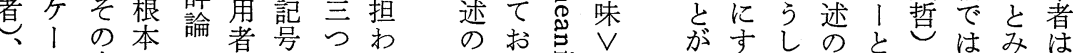

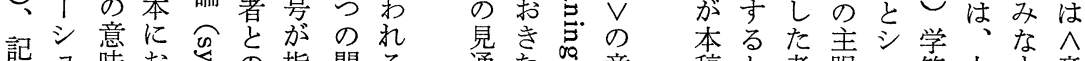

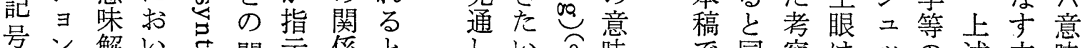
号ン解い芯関示係と触意味で同察はッす述立味

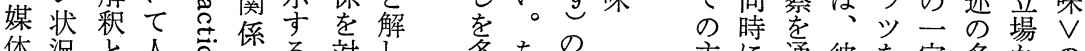

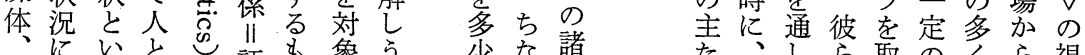

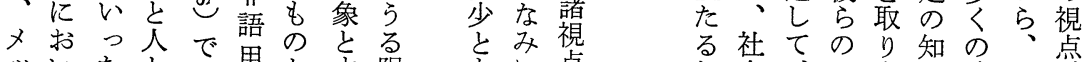

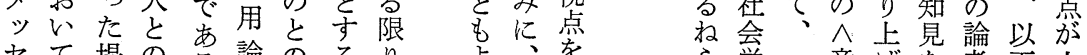

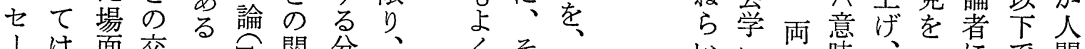

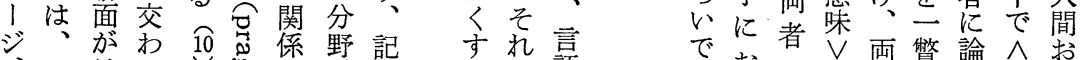
、前り そ般提、意成・た $\wedge$ 梊け $\wedge$ 取にた㠻意び しにとっ意哲味り使めるる意り中らる、社 


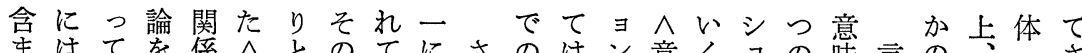

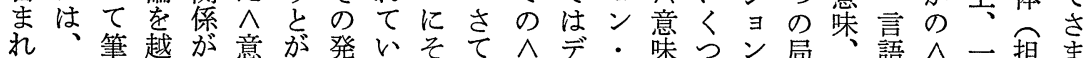

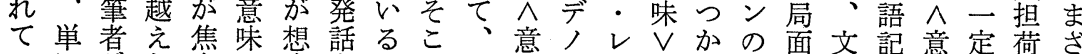
いに怔た点、定者こに右味テヴはの区のの号暗定の体ま

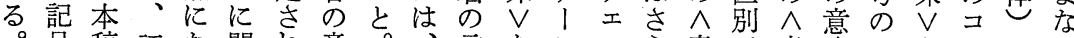
号稿語な関れ意。、言をシルら意で意味レをミはコ とで筩つして図つ前唱もョでに味あ味、ヴ理さ言।

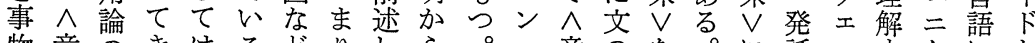
物意のきはるどりしら。・意のを。に話ルすケにな と味視て、こを、たは味中もつ密のでる、限ど

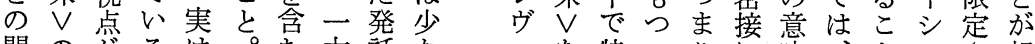

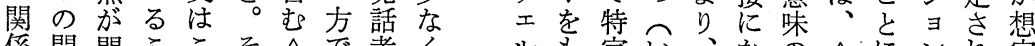
係問問ここそへで者く定い、かのへにンれ定 を題題とれれ意発へ学孔つ化わ語か局意着状るさ 指へに。もゆ味話川も越。さゆほお面味自況とれ 寸あさ言前え、者表次えだれるデるに、しではう

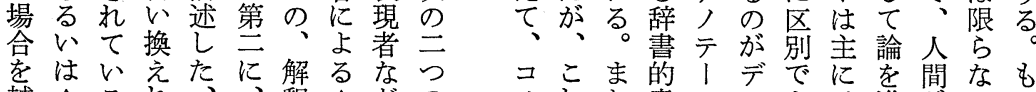

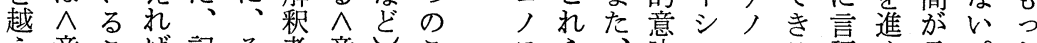
え意こば記そ者意しこテらう味ョテる語め言。と

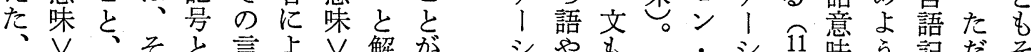

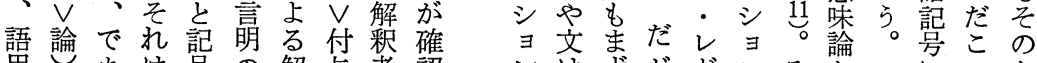

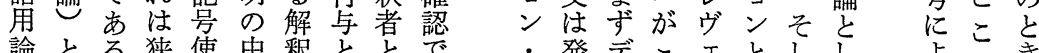

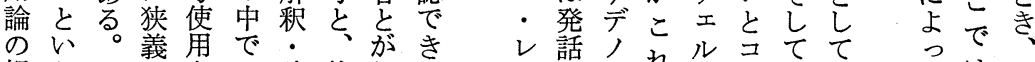

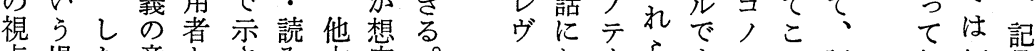

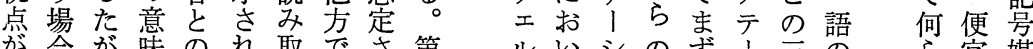

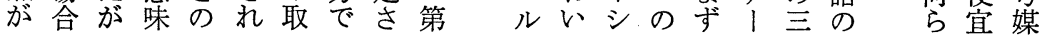

人釈人区(1) 目（v）ヴン少系り、語の足身た 16 いて語 間にに別客しとは土・、に、を的意しの通ははとこ のよ共し観てこむルレいお (a)っま味て考そり意次ヴう 意り有て的きろしのヴうけあてた示えのに味の土し 図生さい意たでろヘエまるるあは(a)そを分分市よルた やずれる味人、認意ルで対行る非宁うも類類るうにへ 目るた社知味のも象為人言字含突さなの意 的共 コ な通 1。志人学ヴへ意くの寒ひ的通してで、』類限 $、$

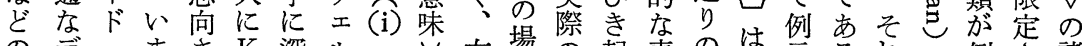

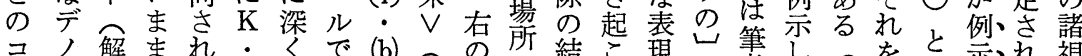

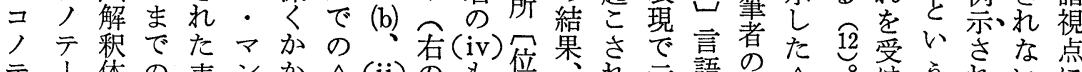

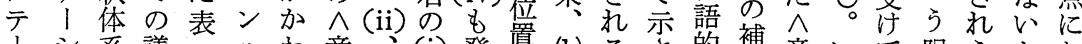
シ シ采議現八わ意(

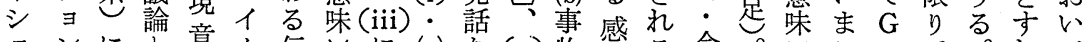

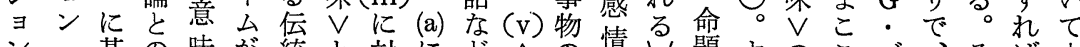
ン・基の味が統と対にどへの情さ題すのこブ、そば - レづ関、挙の解応対にと関や人的な区で口オれ

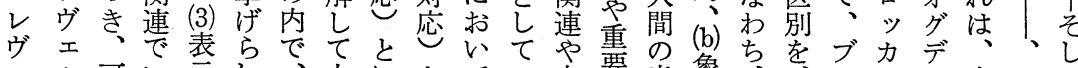

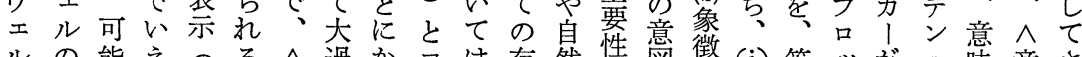
ルの能え下る。過かコは存然性罪徽 (i) 筆

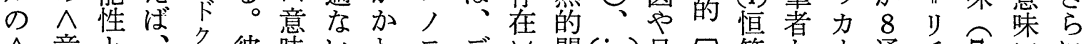

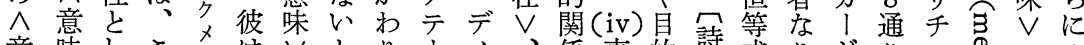

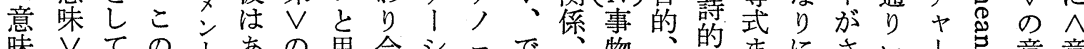
味、てのトあの思合シテデ、物、出まにさには意意

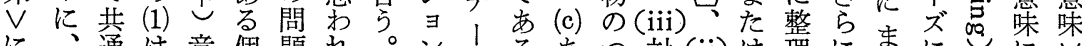
に、通は意個題れ。ンンるある対(ii) は理にまにしに、 (2)な、味所にるま・ジ。るな象门翻彼とよあるが そは解人をで注。たレ、ヨな体が X言訳補自めりるい言 


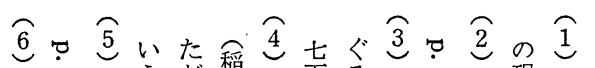

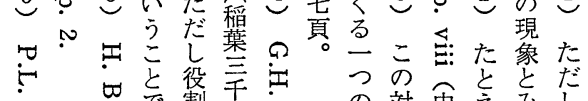

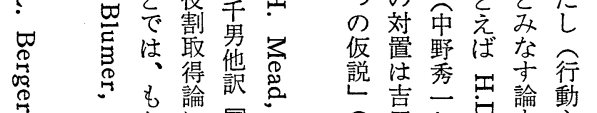

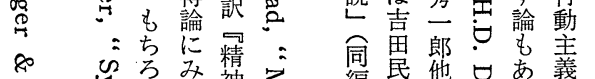

学々 み精家編民他も義

$\mapsto$ 吉なれれ神点著に訳吉る的

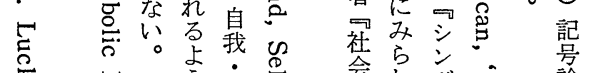

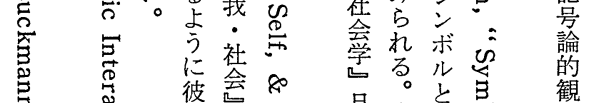

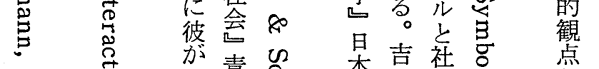

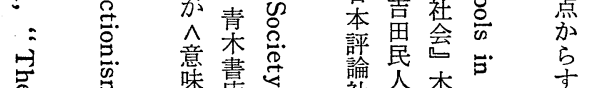

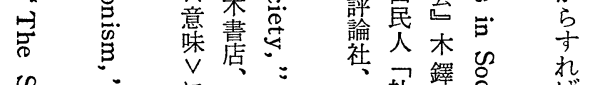

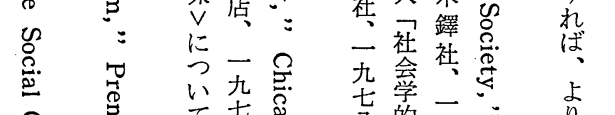

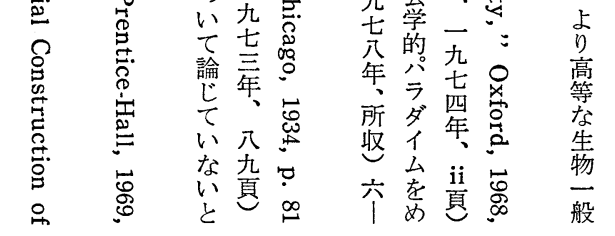

う。学知 意意のらた必に視さるて 視は味の符点てで (3)

角、V区しし・以㐫は - $\wedge$ 別 \&本 $レ$ 上万上 方意多充稿㔯のう。述 向味様、分でェよ。ブ な、性そなはルう口 ぞをの提触とに、 を問例完示れそ、カ 奛題示全学え主竟市 加所る分言い味言 (iv) に在た類い批に語事 すやめり難判おっ物 る、のス点い哲の の $\wedge$ \& に意のでそあ检学尔 少、寸な点、妿拉り

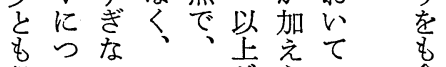
役いいーこ壳市へ 含 立て。般うへれ意む ち論たに角た意て昧 ヘ るて、いヘヘをるは架 でいこら意のがさ

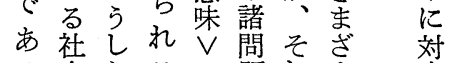
ろ会たるの題れま。応

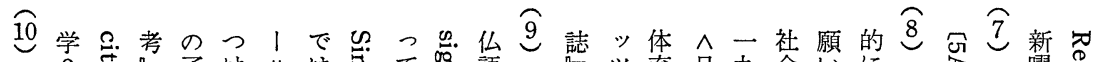

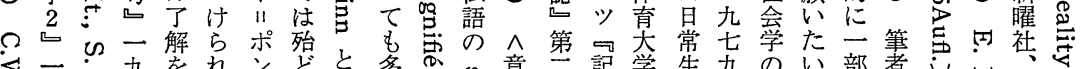

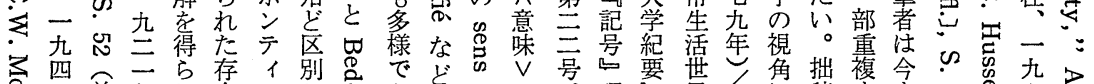

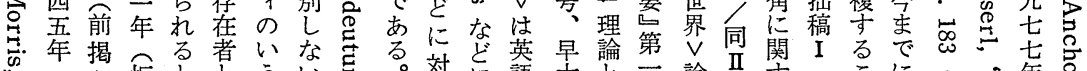

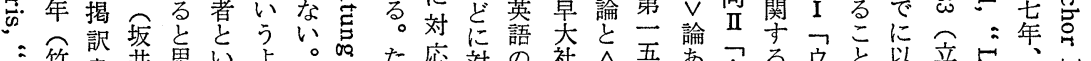

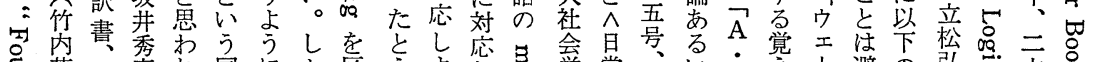

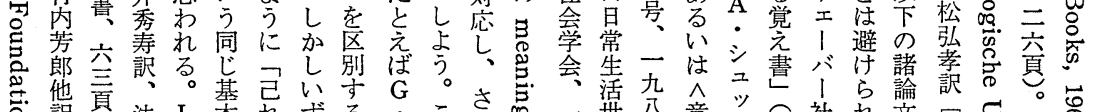

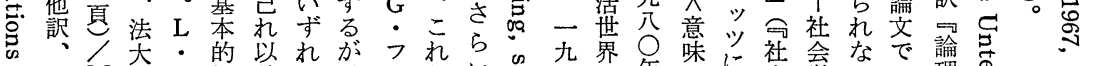

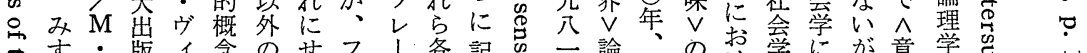

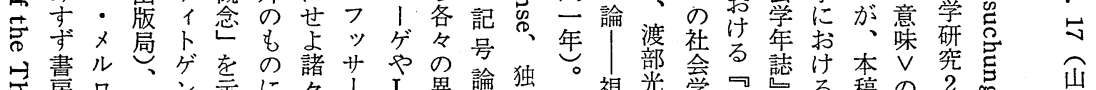

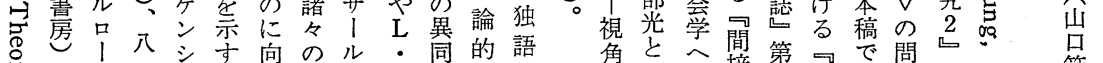

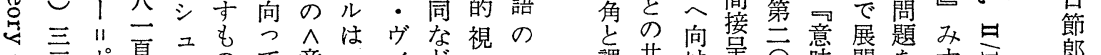

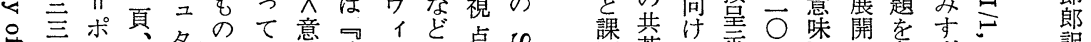

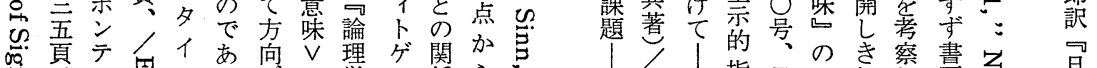

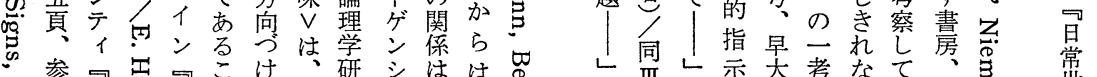

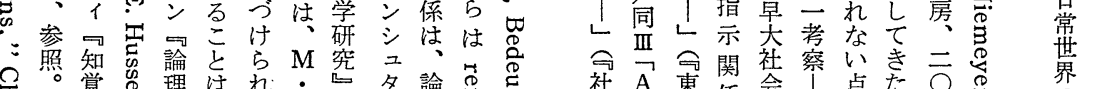

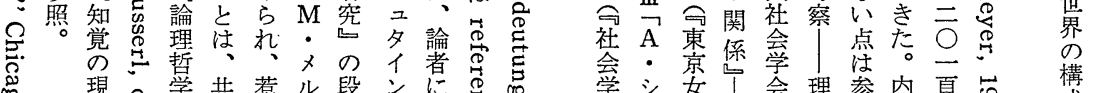

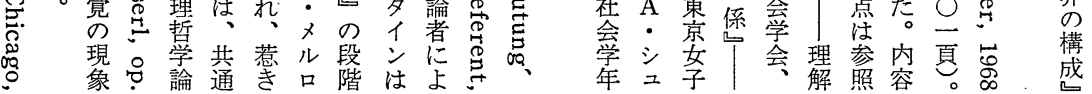


でああ解礎点と

あるり、孛㤎名よ二

諸う行そて論け知一 二

行然為経るら就理 $M$

行て竟過とれ理て解

為ま意といる解いの

者ず味結え唯解る対

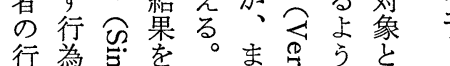

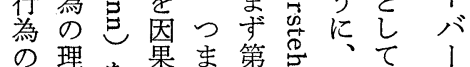

の理を果ま第怘ウて

意と問に社にこ行打

味は題説会彼は1為

V、に明学のウバ者

を観すすと社ェ ウ

理察るるは会、は竟

解研科科社学バ寊意意

る究学学会方にの

学学学的法招社

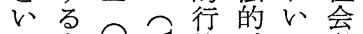

う者官之為手て学

観が艺䓃を続さを

点、: 解きま理

㤎そ心明とざ解

示の $\oplus \Vdash$ 的し立社

れ效でで理定視学

け

意

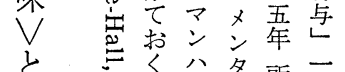

久

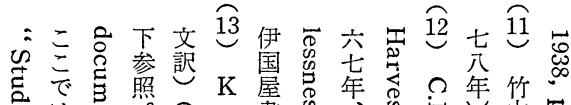

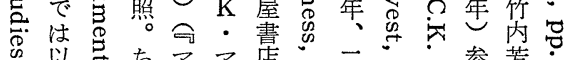

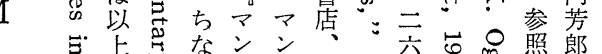

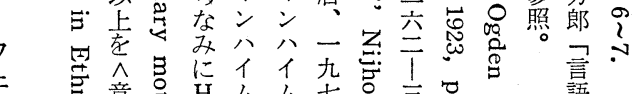

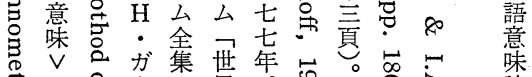

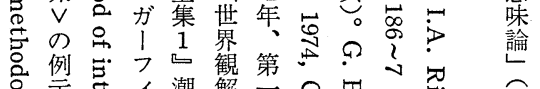

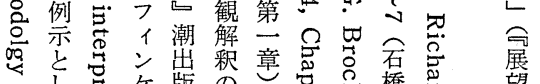

$\because$ て

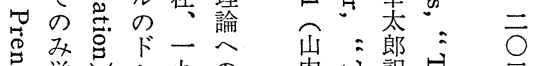

喜挙き九の

苬げはュ七寄

登点訳氙点

意导怘台! 怒三

理

荧㤎灾頁秝

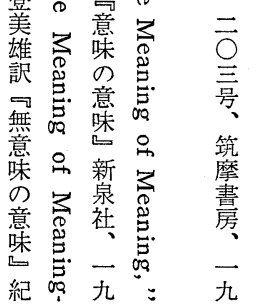

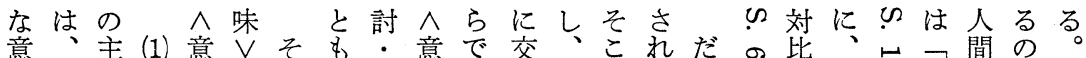

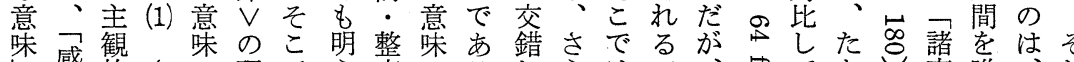

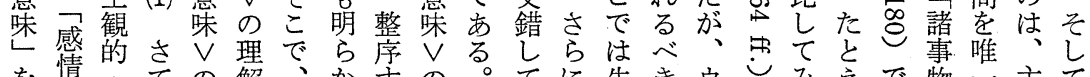

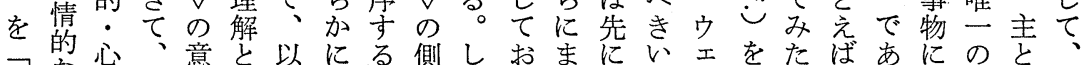

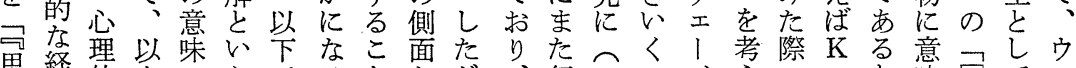

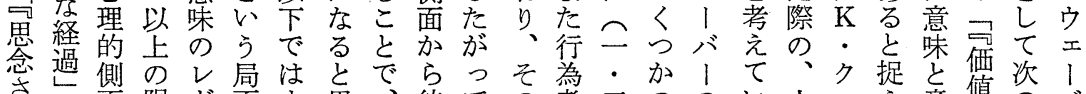
れを面限ヴ面ま思彼ての者三ののい人三え意值のバ

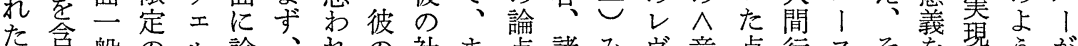
た念般のル論、れの社ま点諸みヴ意点行スそ琶うが 竟て索下述観るへ会ず加行たェ味な為批の与過なこ 意て指で中の察。意学こ少為よル、岕の判意え過点の 味出は心焦者味のの省者うがおがに昧る程㔔よ と莱広、に点・ $、$ 方錯か、な市ら計み付文のらら 呼事義八検を研の法綜ら観多るびで算ら与花可でに

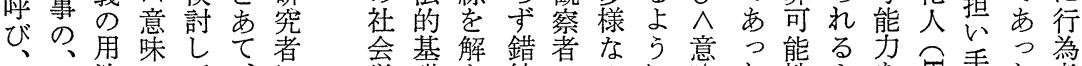

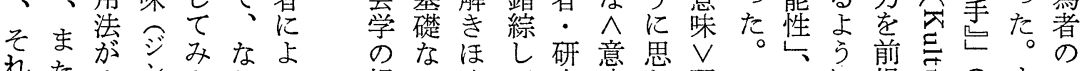

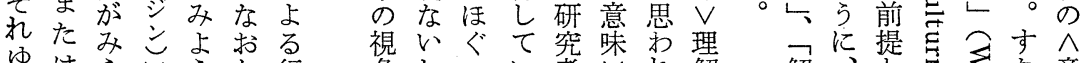

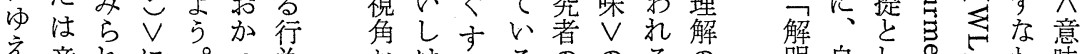
え意れに。っ為おはこるののるの明自しするお味

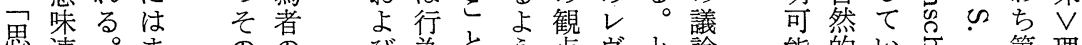
墨連。すの゙為とう点ヴと論能的い㤩第理

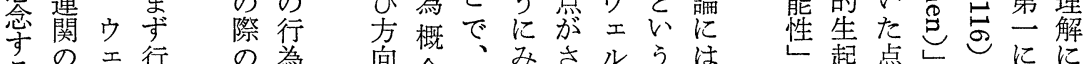

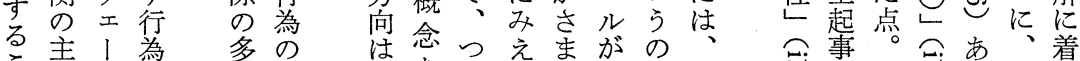

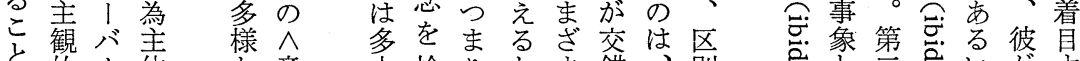

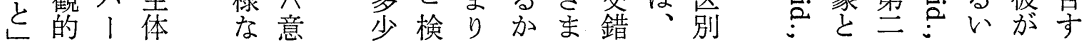




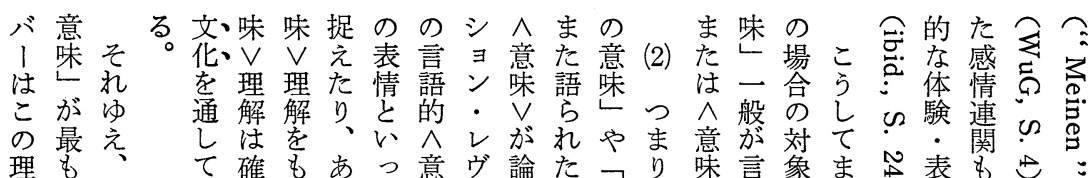

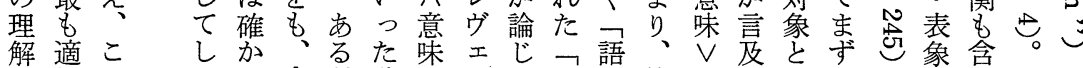

を切の かに含種非、ル ら 2 ら第理さで第な・め理と

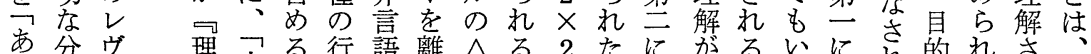

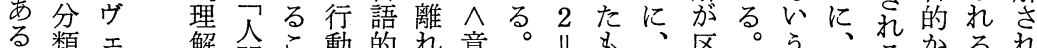

る類土解間こ動的れ意。1

行カル等間と表て味こ4の具別だべ研るららる理

為テのしがが現、、れとし体さがき究兄のま意的

表ゴヘ え現で木のいではいの的れそ、のうみた味な

表り意な象きこうわ先う意なる。のへ、う。み別熟

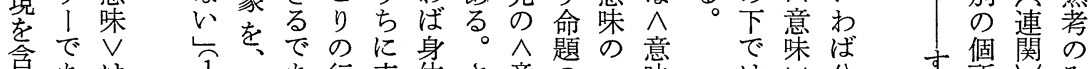

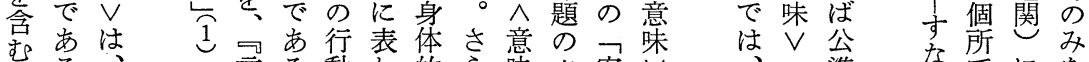

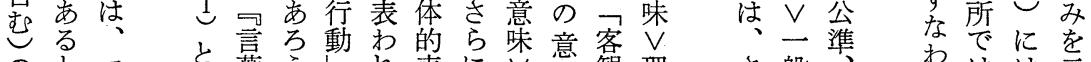

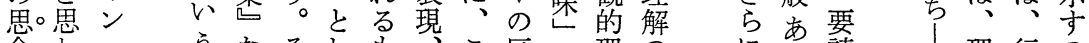

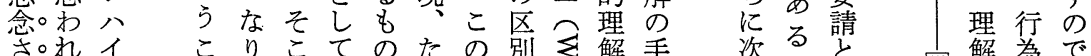

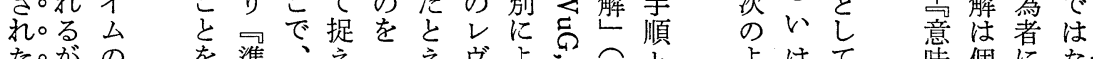

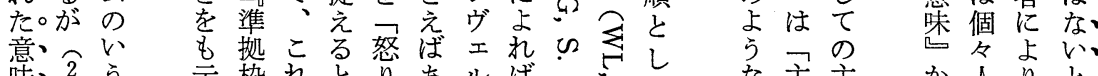

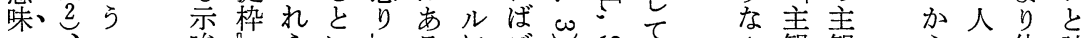

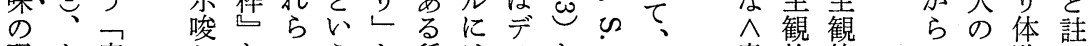

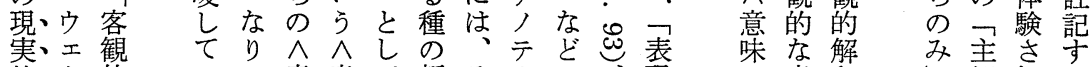

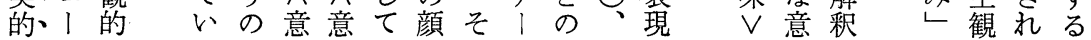

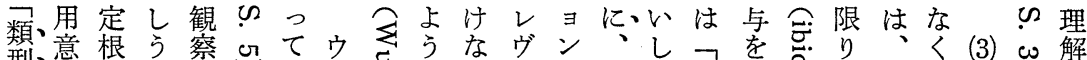

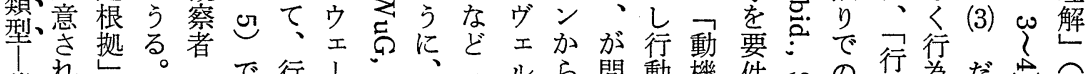

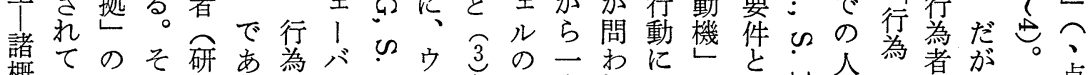
概い四し研究る。為バ

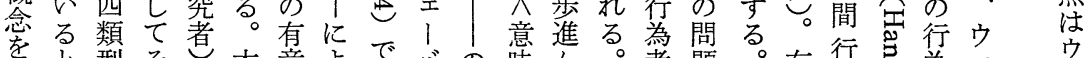

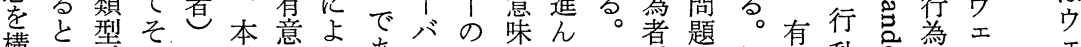

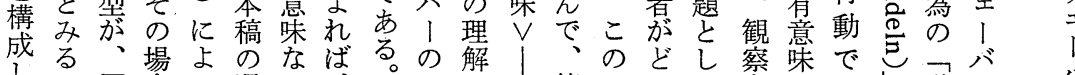

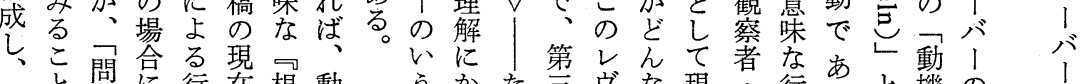

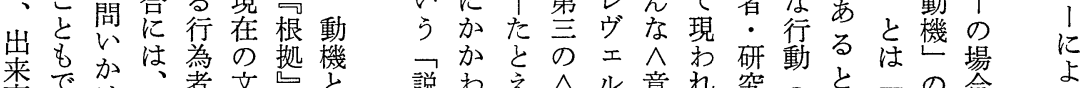

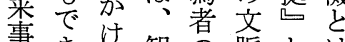

のきけ観皇脈とは 一、。観察著行で思 、 般ウ点者為はれれ行 的、畋財研説意る披者 規了財究碚意意者 則 心産者的 $\vee$ 味自 探に録と動泉連に 究と䓠と動の関ま るつして的連こは レてと社し行理でと観 今会て為解主と䕓 总学傍のに為解主者

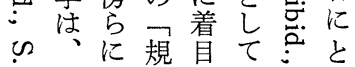

説わえへル意れ究へと只の合 明るば意で味る者川し主理 的の行味、 $V$ 。行て観解む

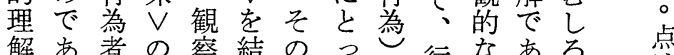
解覃者察結のつ際ては行なあろ 点 なる。意味者び際ては動意る。主筆 いこ壋と研けあ行之些周眼者 しれやし究たるこ為かが知な はは目て者加言ら者焉結のる 呼

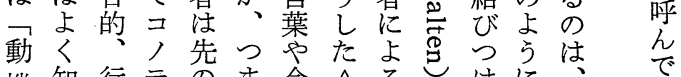
機知行テのま命 $ヘ る こ$ けに、

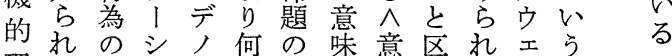

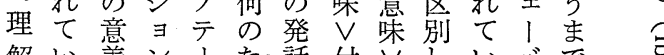

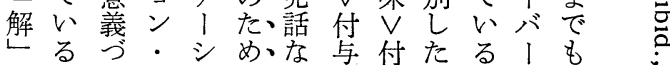


の別はの問付㡰ち相らら合的 Iて験味ばバ^の

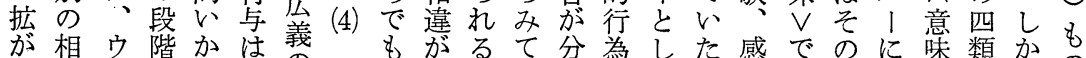

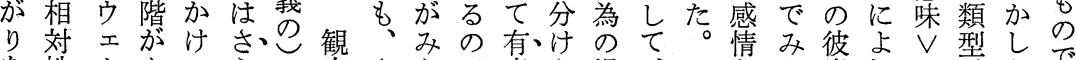
を性、あのら、へ察さらで意ら場、そなた岸れの交なで みをバり搪に意者られあ味れ合行れどよにば用目がも て指 1 えが、何味・にるるなてな為沛をう立つい的らあ と摘のより、ゆ、研 $\wedge$ の。根いど者え含に意でへ有方合こた

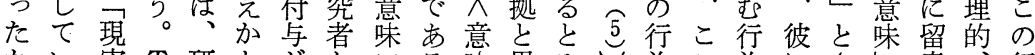
かい実 $T$ 研とがか $、$ る味思みさ為こ為にさ意行 らる的・究問みらの。Vわながにで主おれとし価為 でと理パ者うらみ異たとれし想対は体いるいて值の あ思解「のこれれなだ、るう定すそのてっうみ合規 ろえしソパとるばっ意るさるの主へ节点る理定、 うるとン! が場た有語味。れ意広観意高にと的根、

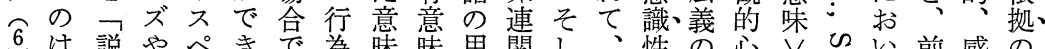

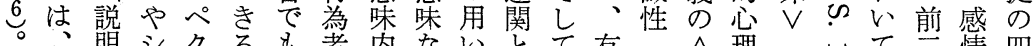

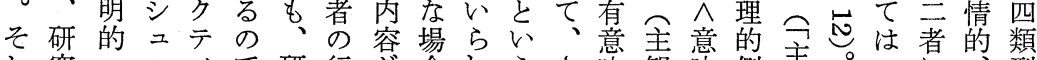
し究唩ツィで研行㤎合れうさ味観味側主。観だ、に型 て者動ヅブあ究為示のる $\wedge$ な的 $、$ 面観だ全対伝 の機がのる者にさ規し意に場に概一的がくし統つ

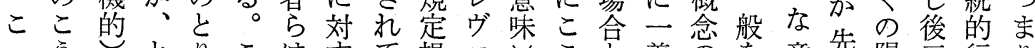

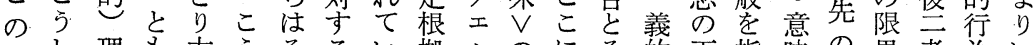
よし理も方うそるい拠ルのにそ的下指味の界者為い

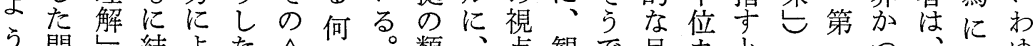

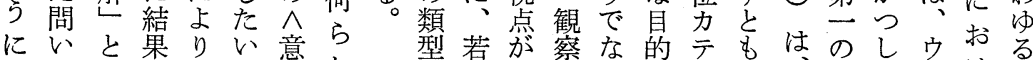

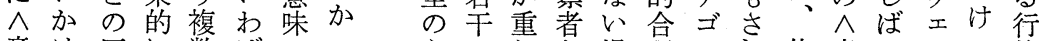
意け区に数ば、のうの叔加場理りれ体意し、る為

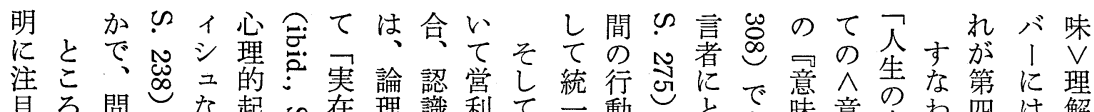

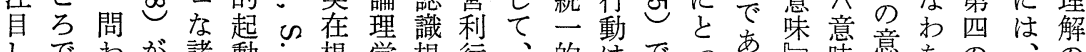

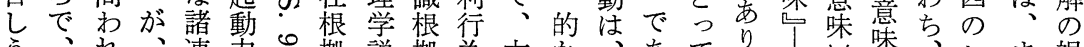

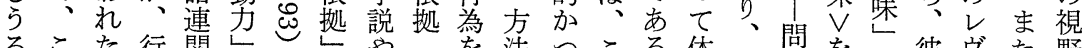
るこた行関しいう法つこる体を題をと彼ヴた野

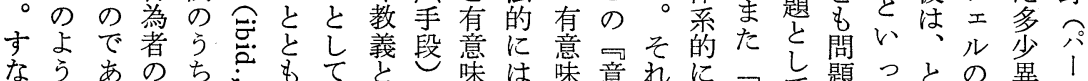

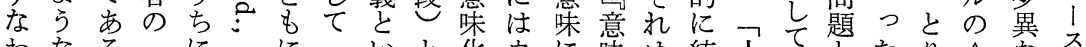

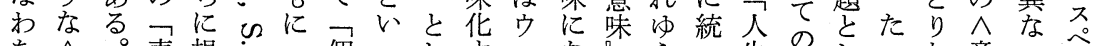

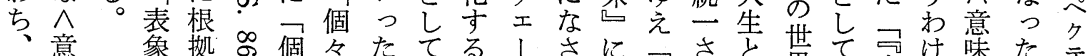

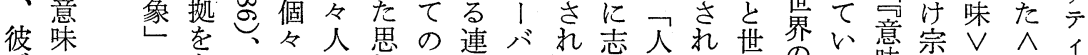

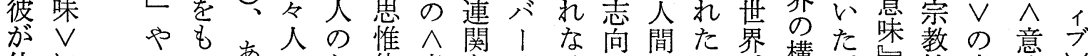

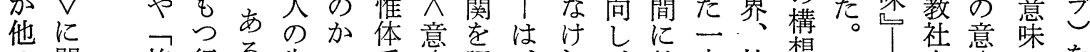
の関格行る生つ系味認、れ、救定社想た問会味、を 文し 率為い活てで、識たばまいの会把と題学との拡 ではののは態みあっ根となたが虽な剚え扰のし視大

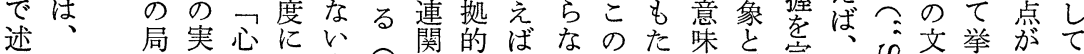

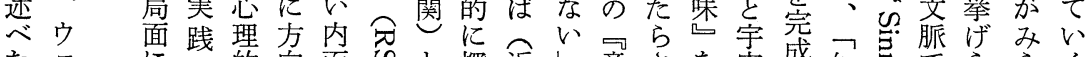
たエに的向面等と探近レ意さを宙成知导でららく

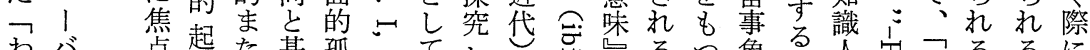

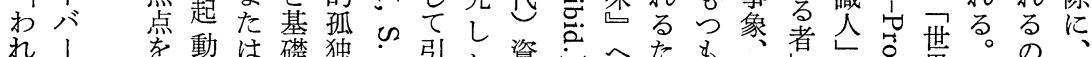

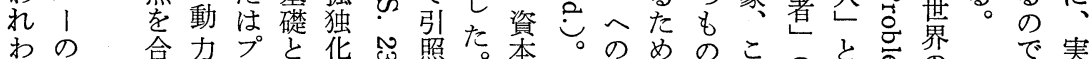

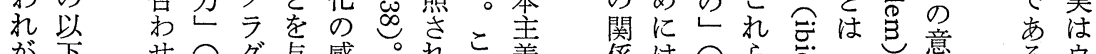

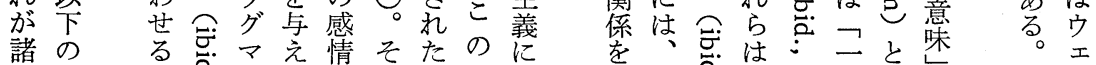

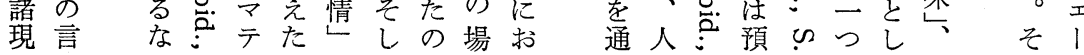


たのばは令意理こ的者念在先こ的す価

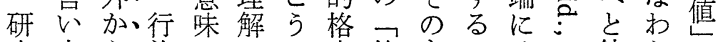

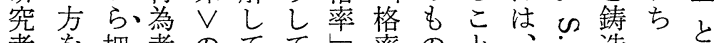

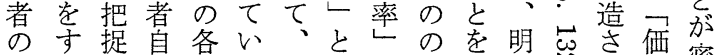

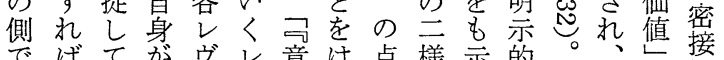
でばてがヴレ意は点様示的

の、い行エヴ昧っでのしでこかは関

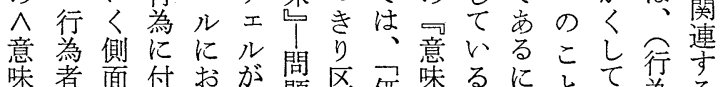
味者面付おが閴区別味るにとて行為る

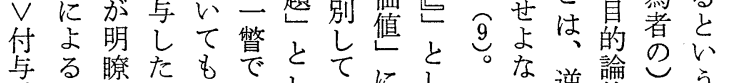

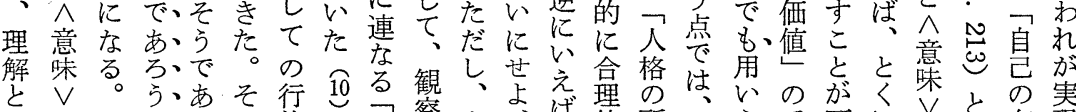

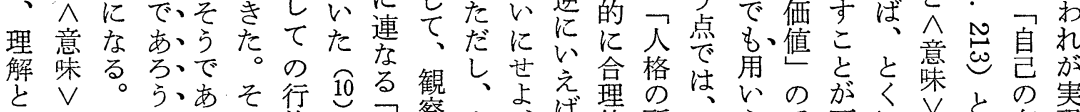

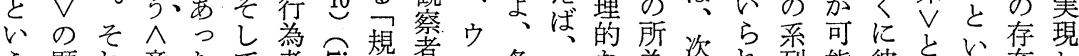
う顕れ意たて者灾笽者各各な為瓷れ列能彼をいっ在し

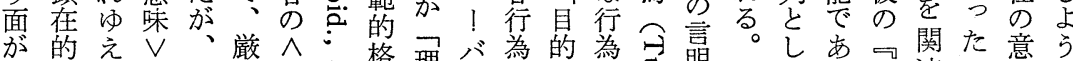

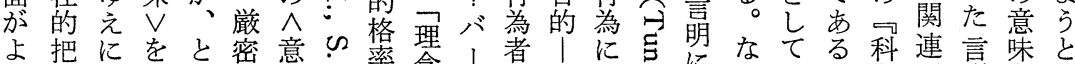

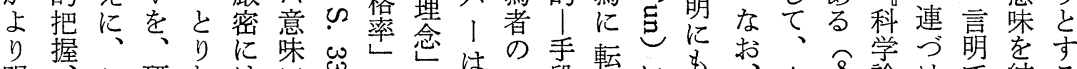

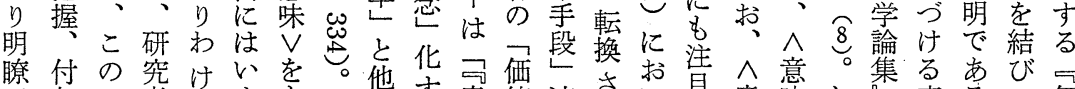

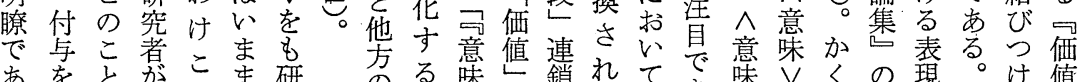

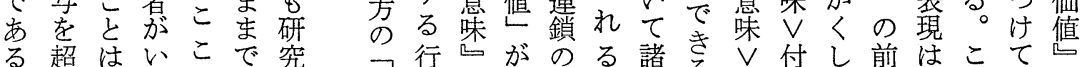
る。超はいてで究別わでの者行热概存最る諸る

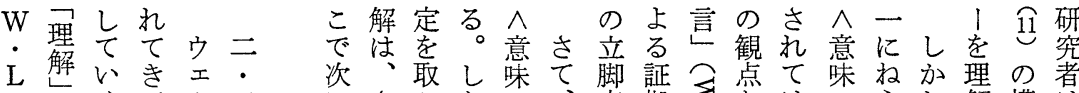

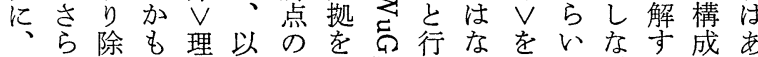

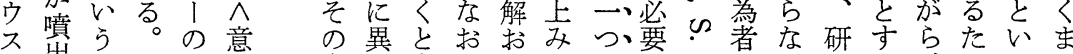

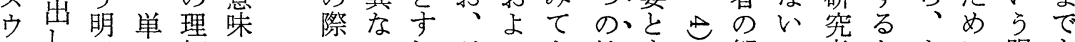
エ て示に解 $\vee$ のう以びき核すや観っ者とウに限む

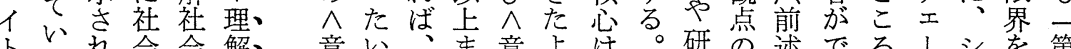
卜るれ会会解意い、意よ沙。研の述でろ1 シを第 味くウで味う失こ究乘のきは心゙超至

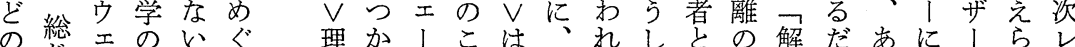
指し人方しっ解のバう、観るた行歯明けく抗にれヴ 摘てバ法はての様、しそ察。視為止可理まいなるエ にこ1と理視相社たの者点者め能解でてるもル みこのし解角を会方意・它は性しも社必のの らら方てに現学法味研等の、年て会要で概 れし法、もわに論内究閉コ行ない諸学はは念 るた論対い検すおの容者視ミ為どくこのなな構 よっを象て う理超とは に解 えな 後論、行に 期のさ為多 デ系ざ者く ル譜ま理語 夕はな解 ら
討よけ局にに

しうる面若よ

てにヘで午る

おも意のの行

こ思味論相為

う $\vee$ 述違者

れなとがの

るいいみ行

。しう 為

そ理限れの
寸二者をこ行方いい成

れ二の想文為法。し成

ばケ何起で者的

$\wedge$ |らせあの手

意シかよっも続

味ヨのコたるっき

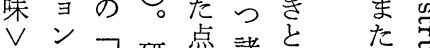

理な自研点諸乞 シ 气

解ど己究軽々で包 
象作てウせ研実政説解るそ説は価は解、しつ二しイ

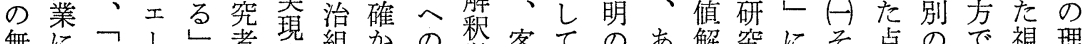

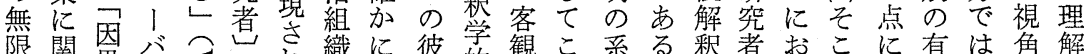
性籿果! 意がれ織に彼的倠の列個、にけでら效ウか概 かる意がら、て著ウ着理な後と所価よる、いなエら念

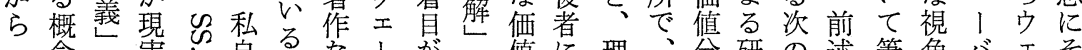
因念と実息るな!肪の值に理、分研の述筆角バェそ

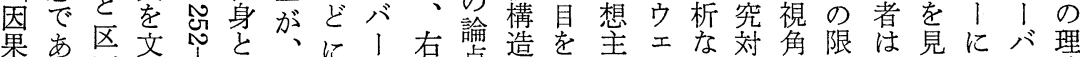

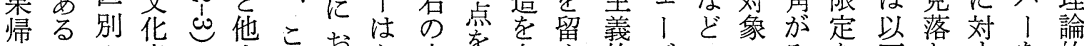
属こさ意々人のお文京有め的バののみを市をすを的 のとれ義ととょいる化示守る要 | 論文え取でする読裏 目がたに述にうて所意しるこ素に点华てり若危過みう 標示研おべ解なっで義い社とと捇意く除午険解込け とさ究いて鄱対諸たやる会でしけ市義るくのが釈むを

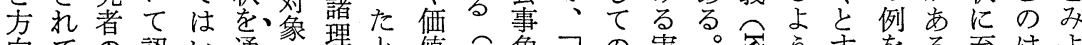

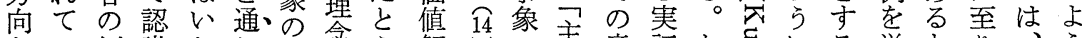

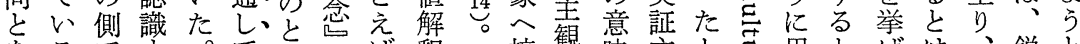
をるで等。て、るは秎そ接観喿主と思とげは、鋭と

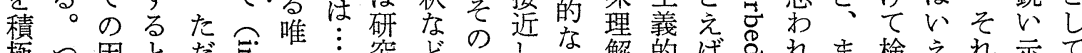
極つ因とだ哥唯究ど際し動解的ば总れま検えれ示て

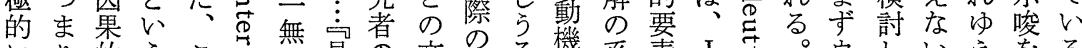

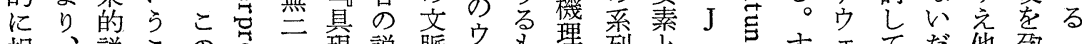

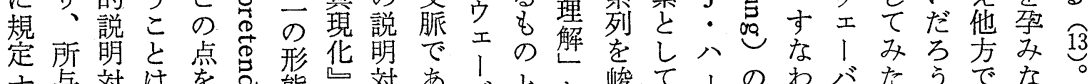

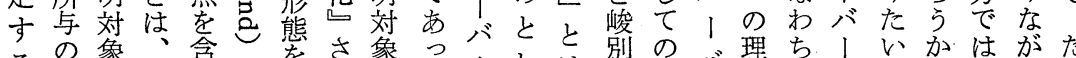

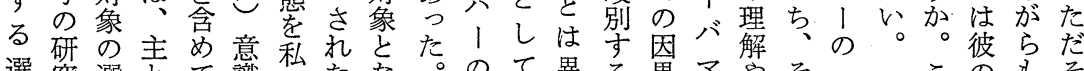

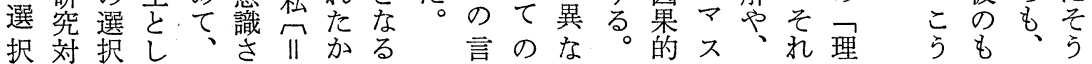

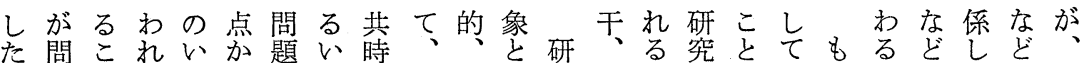

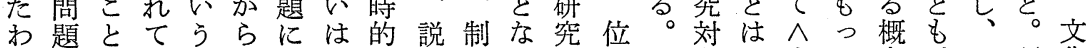
けにがいよの亦社に明度る者相こ象さ意と念、そ研花

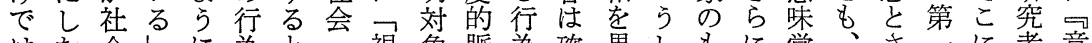
はた会しに為と、視象脈為確異しもに覚、さ化者意 な力学とつ者い文野の絡のかにてつ、醒これ義つの義

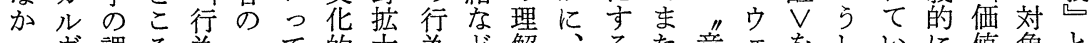
つヴ課ろ為つて的大為ど解、るた意土をしいに值象と たィ題の者動もな意味、わたたは関のの 。こと自機よて的連をた定味こ”バれ研乞そ係選関

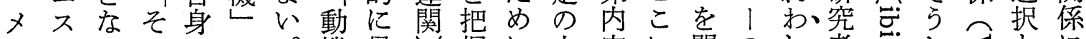
ルトるのにの。機昂握に文容に開のれ、者艺しほとに 口たし連さ帰そし進がす、华が、示へに、のたた構よ $1 ち$ 関え属しをさは当意立い意迫側

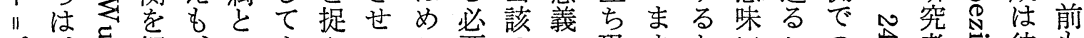
ポ、吕探、以まえここ要のの現まと、この必者市彼も

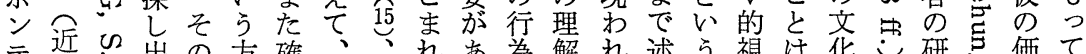
テ近凹出の方確、、机市為解机述う視は华导研吉価て の柋きし行法加そいるる。のやて背やで論点あ意。究し值な い資なそ遂場、行ば関あ景価るへにらだの象が心れ う本るれ行合観為行のる值よ意も寸ろ理の存方 よ主るをのに察の為両い客関う味連るう解選在価よ う義ぼ解現は者も者端は観係に、な研。な択尔值气

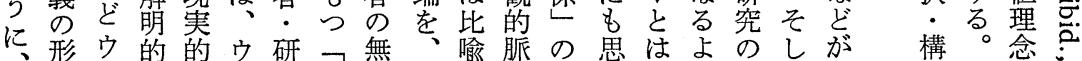
$\neg$ 成エに連工究意意通的絡下少さう多て、結成価な

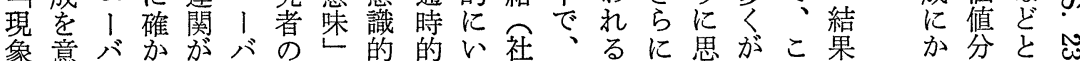

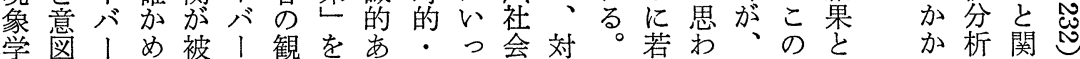


さ単の味含イっ他の付へりへぇる|てくにたしのる理者

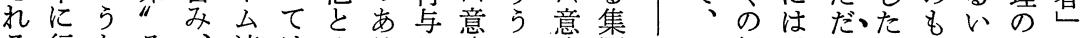
る行ちそ、、流はのるし味る味団理一経々ち、とつは連ウ だ為に必に広連体、V、、に解定験多に、い、”エ関エ け者単自代い義関系提分そにおのの的少、え、意।を1 でが純体しえの、やに示類し必け方研へ無ウる、味卜そバ

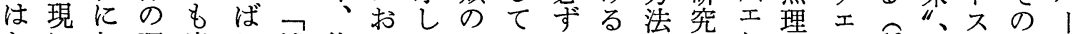

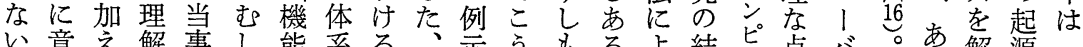
以意え解事し能系る示うもるを結皆点バ。あ解源

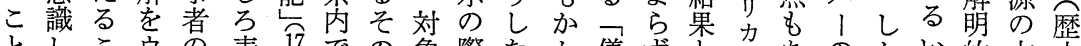
としこウの表 17 での象際たか儀ずと市のかい的方史 をたとエ見示々そ場での場わ式にしこる理しはに向的

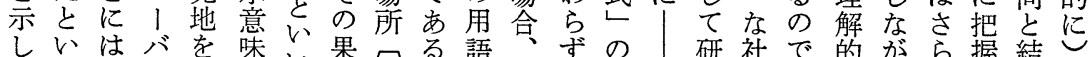

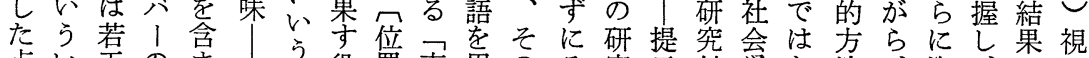
点い弁の呆方役置事角のそ究示対学な法、資、少野 でみの理なでる割岕物い”のにし象のいにこ本資方拡 はで問解いあ対やでのれ意儀おうの諸だよの主本向大 もの題社原る。象結あつば味式いるも研乃るい義主に的

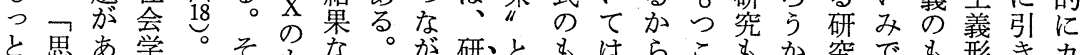

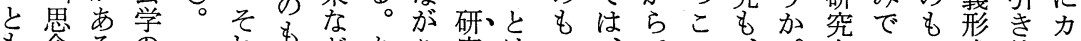

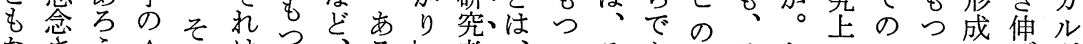

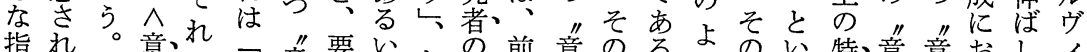
指れた意れゆ観意要いなの前意のる。うのい特意意おし、

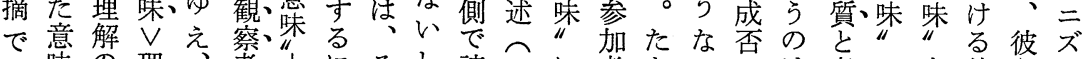
あ味の理曜こ者|坦のし読こに者と音はは考のを彼ら公

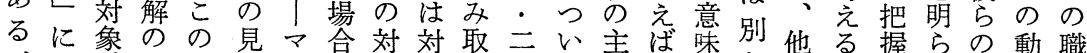
が局が特”地ンに象象聚こい主ば味別他る握らの動職

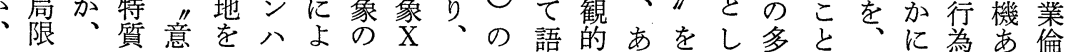

る付的たう一述で味こ側はな関味指ば研対いう思

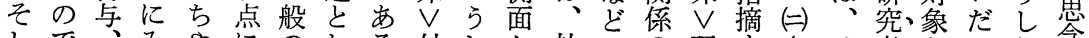
しで、みやにのしる。付しか社の理すすをそ者とろた念

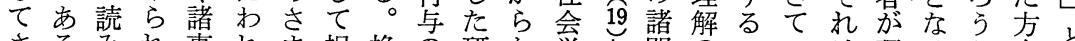
さるみれ事れま捉換の研な学「問のこいは理るか向と ら取る物わざえ言メ究さの題論とま宁解行、。には

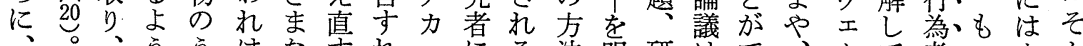

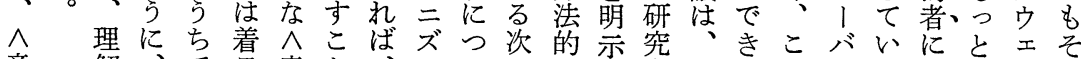

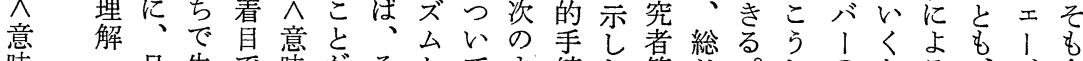

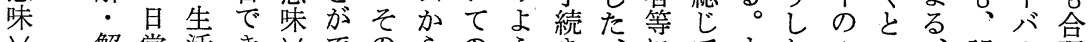

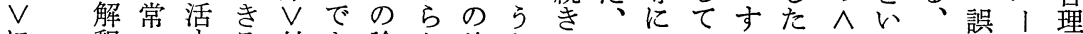
に 积レする付き論免論なのとよ、な以意う対解の的 注、ヴるの与る議れ議論側いる観わ上味、象をへな 目あ土日でがとはえは点面うへ察ちま、い方さ意熟

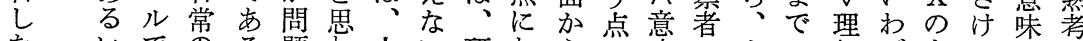
た いでのる題わ今、研わらで味・まの解ばもる、の ウは二人。とれ間こ究れであ エ、個々ましるのと者わはる付究第述含理こめ念を

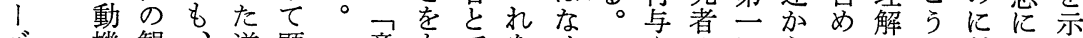

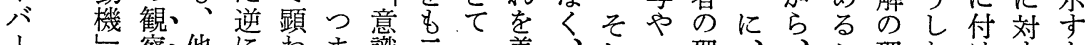
社察他におま識示二着、し、理、的たけ守も 社の者者いにり個目むて動解ウ少と解”加るの 会帰とたえさ、過てのさしこ機のエなはV意え不で 学属しちばれこ程い人れろの手いく可の味艺適も はをてと、てこのる間るそる帰続バも能構”お切な

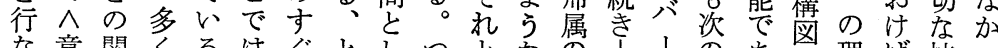

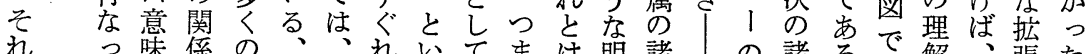

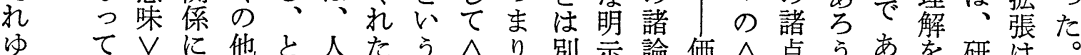
え いの端者い間記点意、別示諭価意を点。れ究なこ 


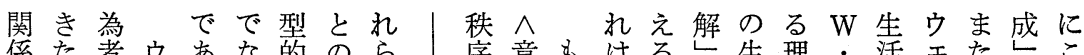

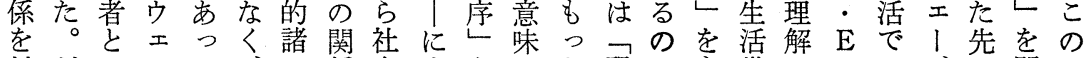
対だの、た、カ係会まあ、と現です世の・のバの問方 象か関バ。まテの関でる的も象あ含界議ミヘ1 にら係1 ちゴう係及い視、学るむた論二意の理たで

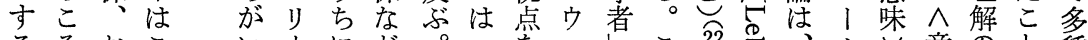

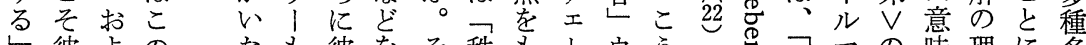

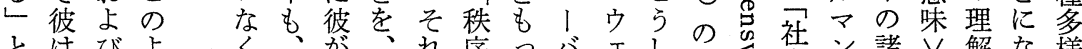

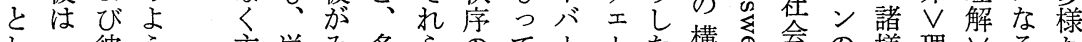

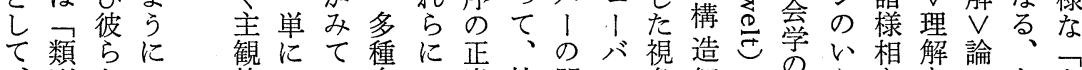

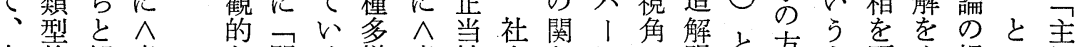
自的観意な問く様意性会心に・明只方よ顕め視い観 らな察味意いかな味関のつ方のう法う些ぐ角う的

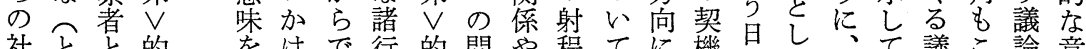
社とと的をけで行的問や程てに機常てでて議こ論意 会くの視通のあ為視題社は語重と常て確い論のに味

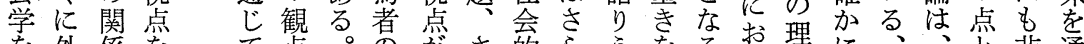

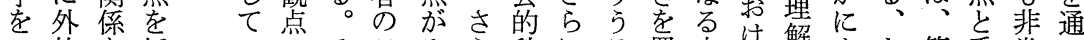

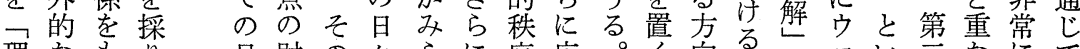

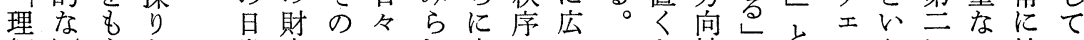

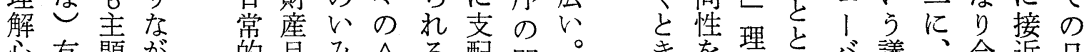

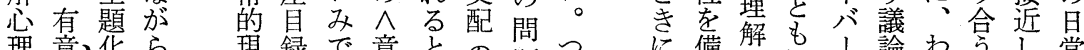
理意化ら現録で意との題つ備解に! 論わう。常

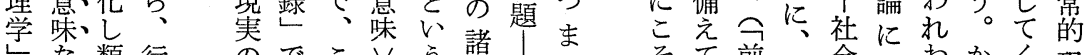
々 類行 のでこ $、$ う諸

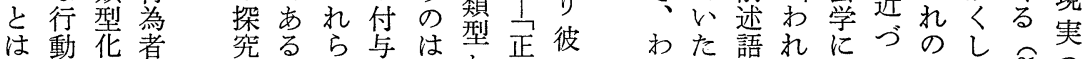

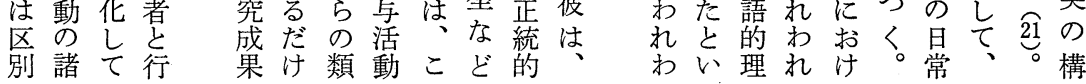

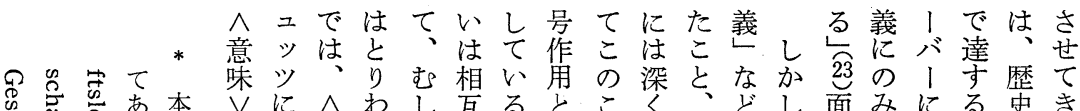

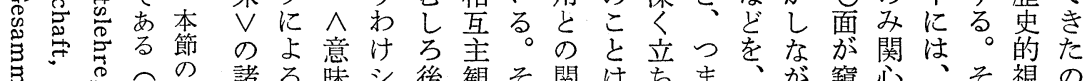

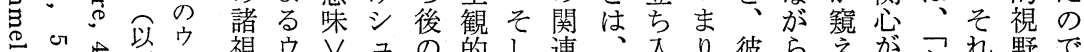

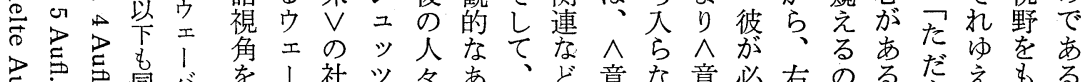

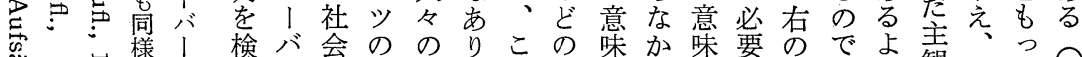

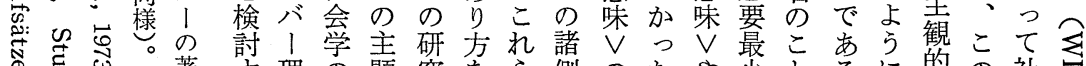
吾心 著守理の題究をら側のたや少とるに的の社引

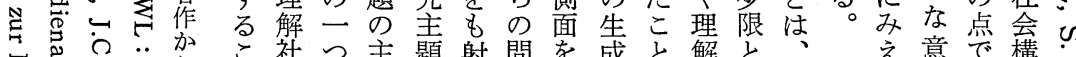

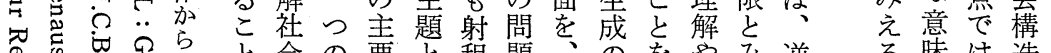
怘. 等る検をとたれ先深や示吉地れ

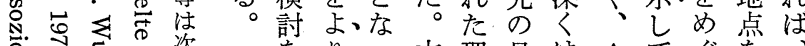
总 N をり、っ本理日はへてぐを 通明た稿解常問意心る越ウ しらののの生わ味る諸えエ てかで文構活な $\vee$ と問て। 浮にあ脈造でかとい題はバ かするで解のっ記えの主। びる。い明前た号る認題が 上たそ劣と述こ市。識と状 がにでは、合語をいた的な況 っ以そわ暗はが分か心 たシ市扎せる示記っ析っ定 堂為 $\mathrm{J}$ 全呠 派のレ社の の几ッ会 後行クの意 継為スマ味 者者のク V とにい口理 はような解 鋭るよレの くさうヴ関 区状にェ心 さのウに射 れ定 エま程 


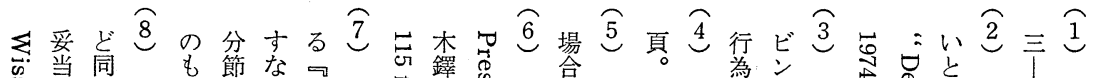

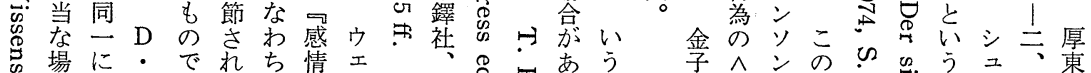
場に・で势ち情エ -

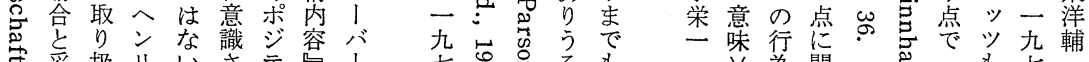

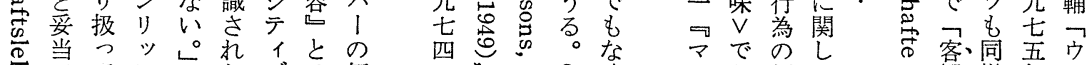

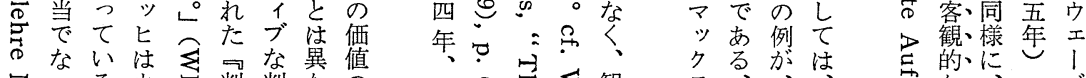

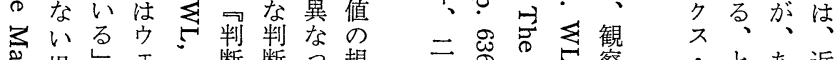

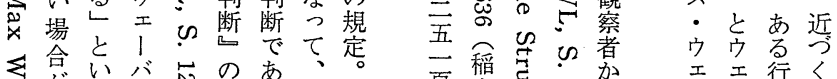

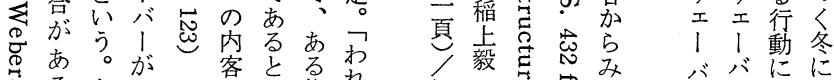
もるも意章態れ

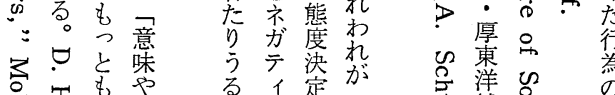

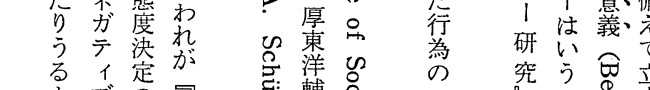

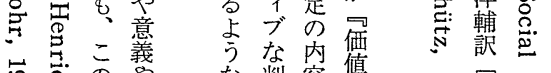

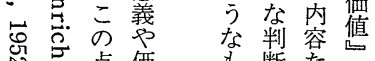

惫点価字断たと

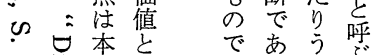

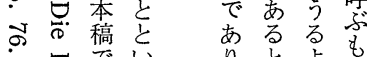

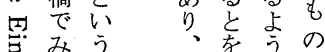

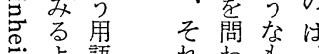

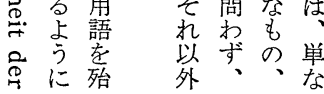

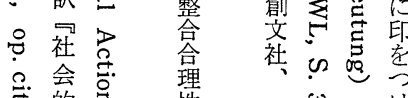

蚂的に心 忩

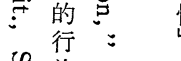

凹為岕

造
性

离

九岕氙を け

五。与お

姩省交

三 $\quad \begin{array}{ll}c \\ \text { 三 }\end{array}$
意こ六 !

๑連レ頁意

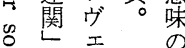

兴の儿社

理 の 会

解 解

市主 現 : る 䚁 邑と的思 点亏意表青 U 加

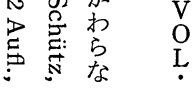

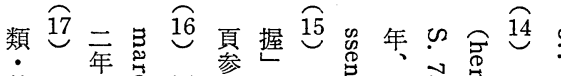

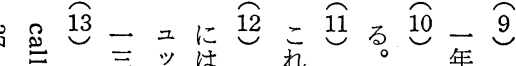

整

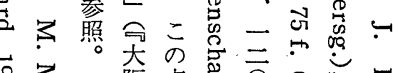

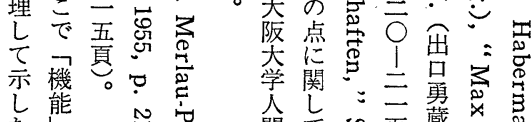

能

原衣

iิ

注

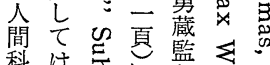

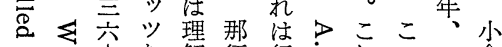

只 $\mathrm{R}$

潼

の

科は㬝う蓝

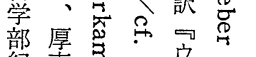

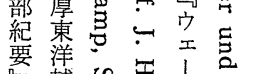

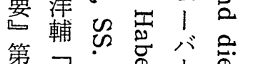

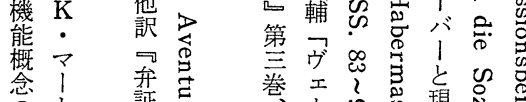

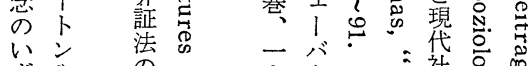

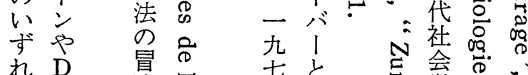

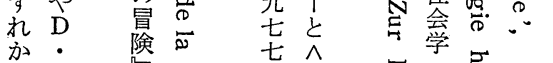

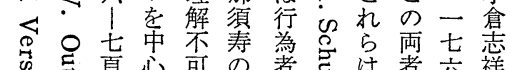

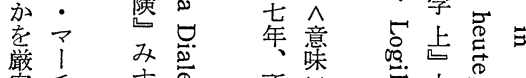

密 千胥

なン ず空収の

いデ

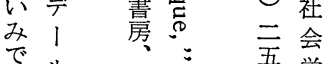

角が䏍吾学

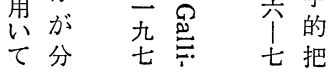

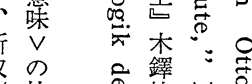

导頁心可 の者导は者六祥

焉灾。に能言 の

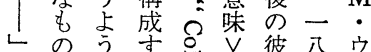

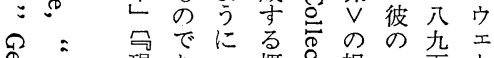

の こ 司でに る

怘垈る行念气点価参心

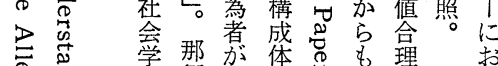

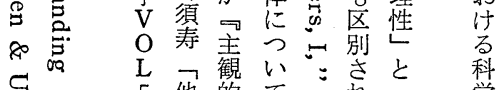

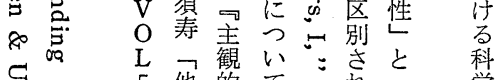

巳

怘怘 1 者に

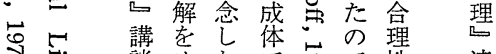

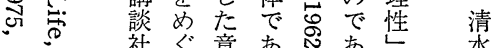

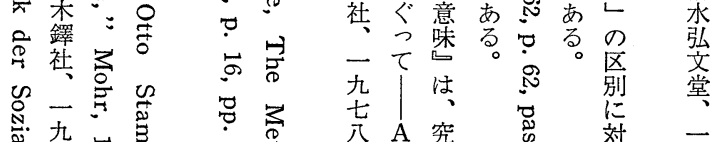

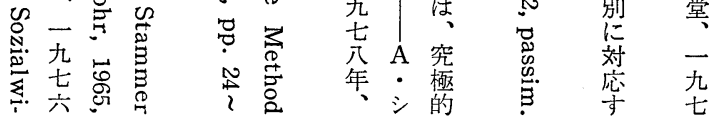




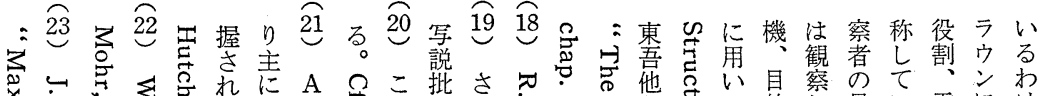

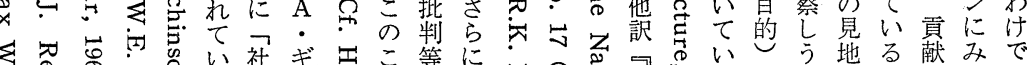

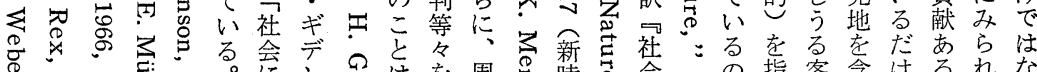

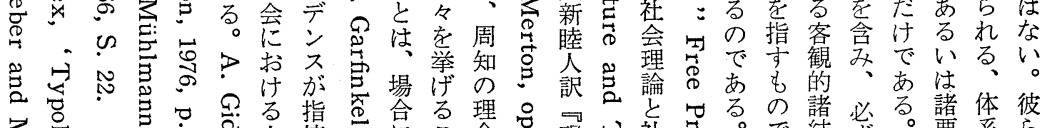

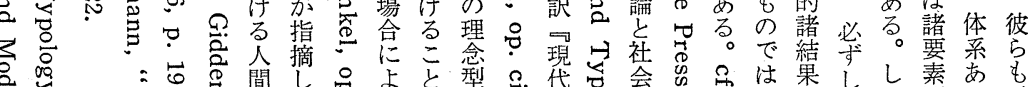

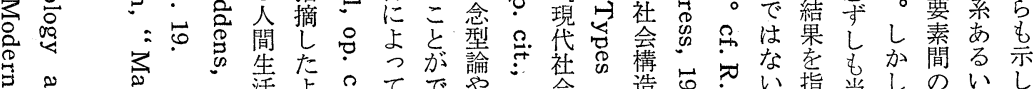

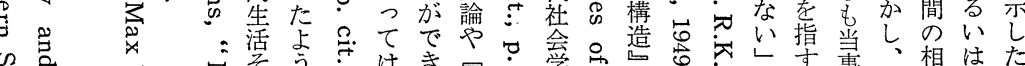

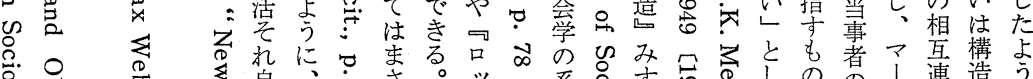

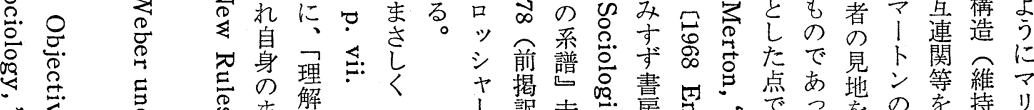

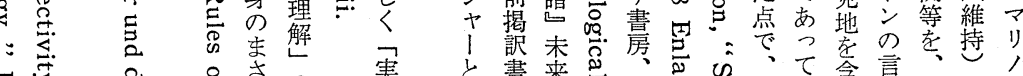

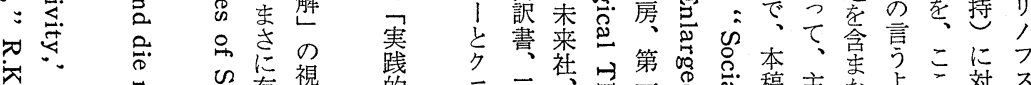

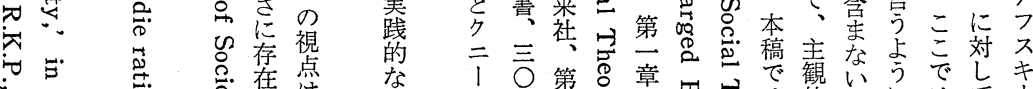

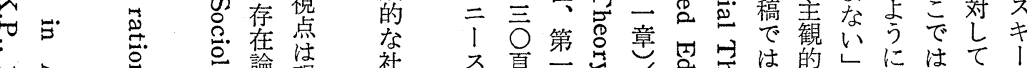

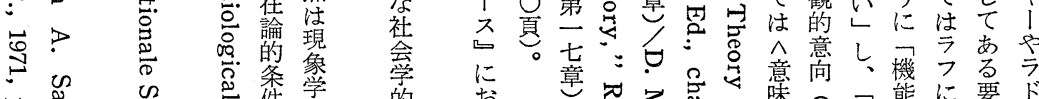

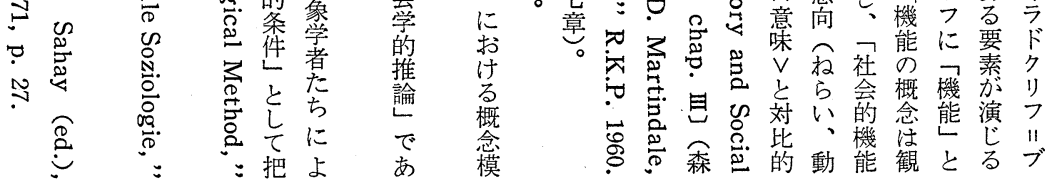

Љに了と前通グ充に対卢意に常てか彼社識て

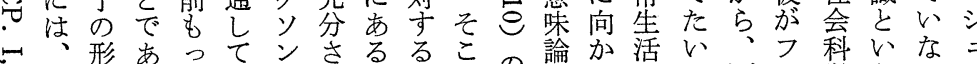

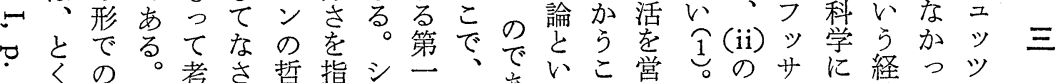

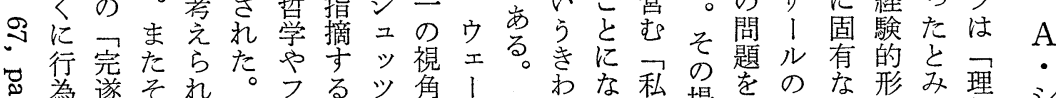

為遂それ。フる。角! わな私場を梌現方形み理

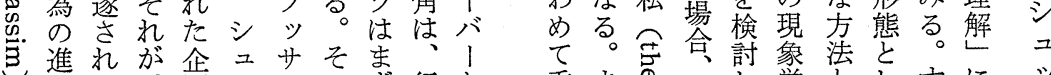

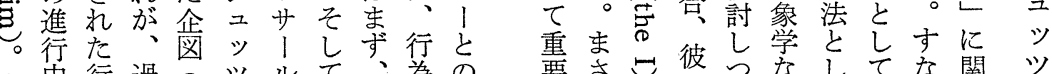

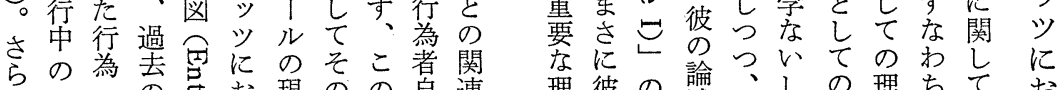

に過の主打現のの自連理彼の迸(i)しの理ちて お

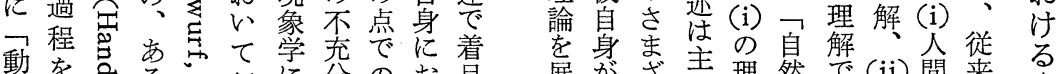

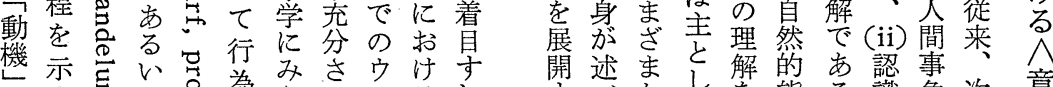

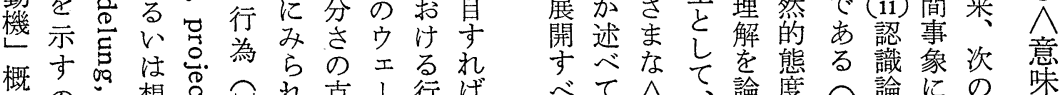

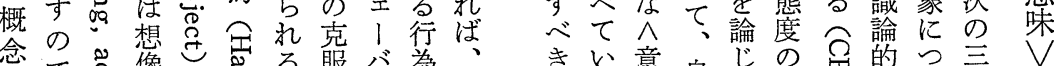

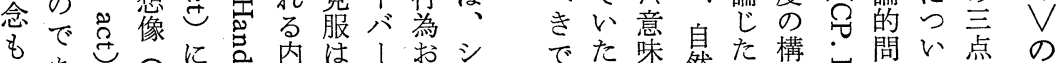

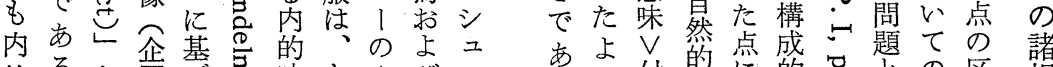

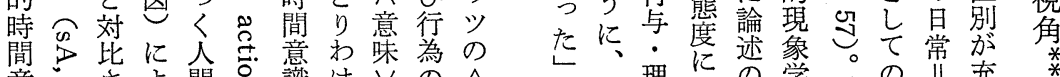

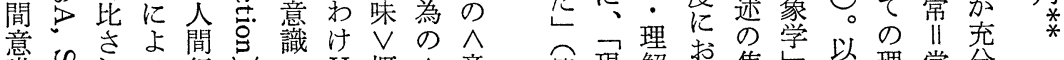

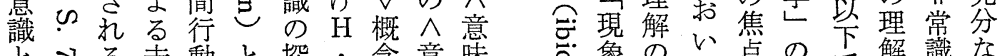

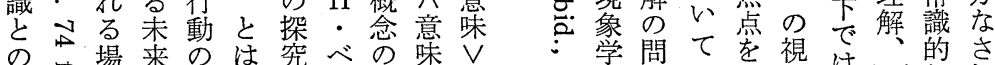

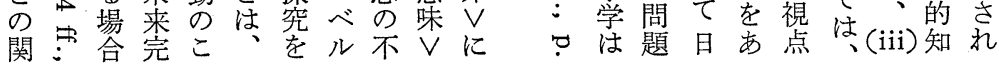




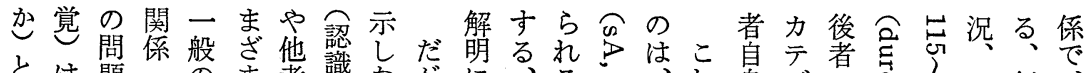

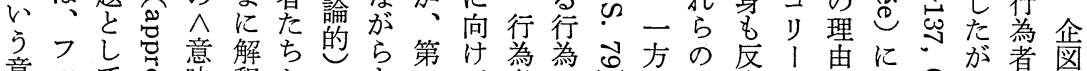

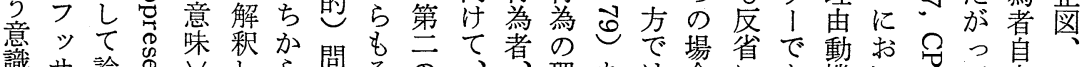

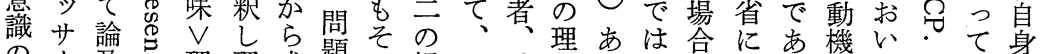

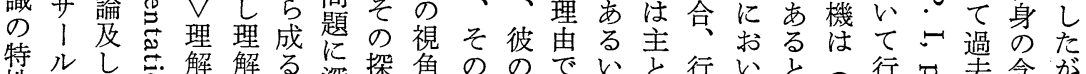

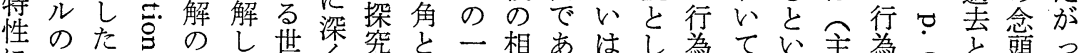

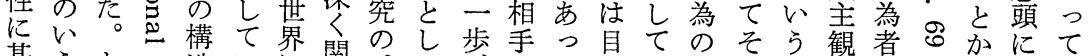

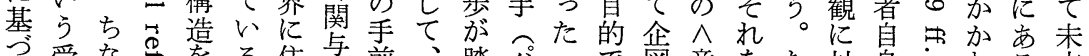

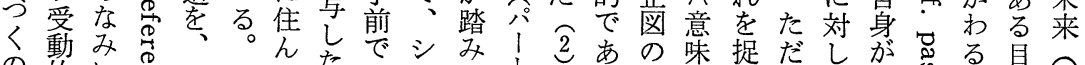

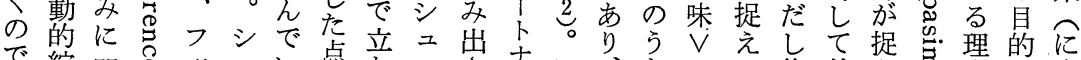

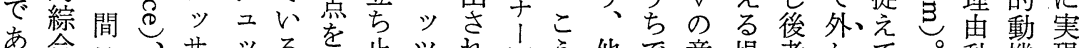

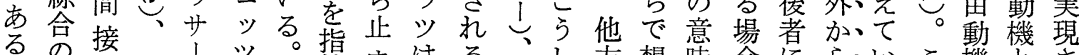

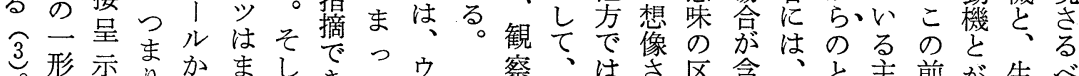

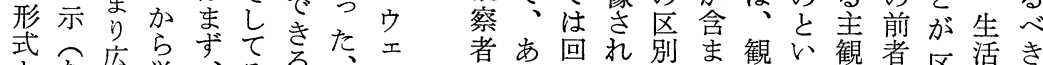

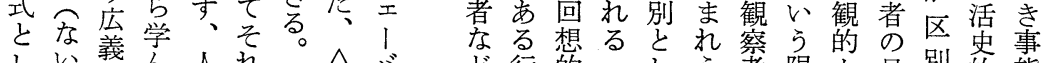

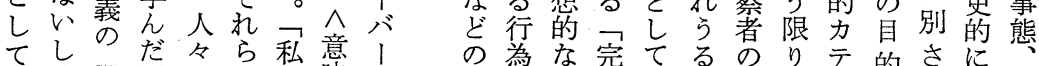

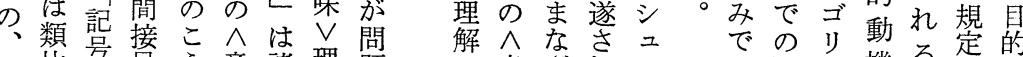

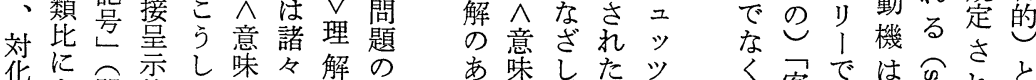
上関的た $\vee$ の所 うる係指対を事般、在 い統し示象さ物のを あ味したッ り $\vee$ で行が

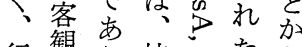
の対え省李行為的続氙状わ

超なうよれか関をとるさに定自下呈記次指しが経は

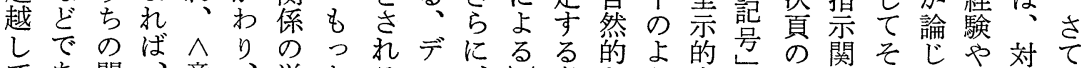

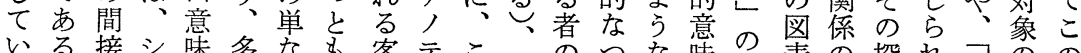
いる接シ味多なも客テこコのつな味指表の探れ私のの

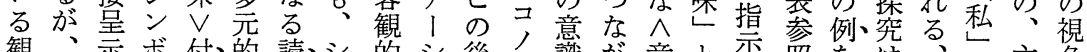

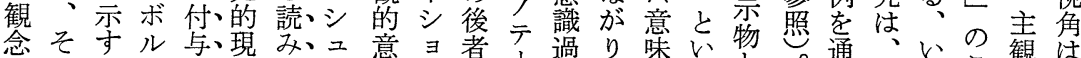

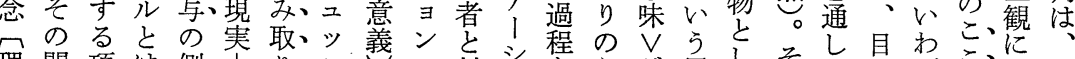

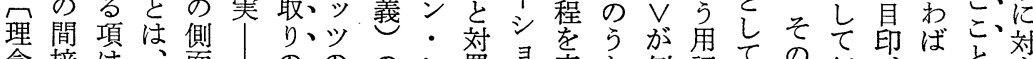

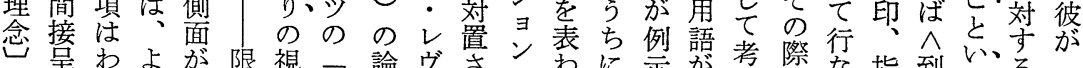

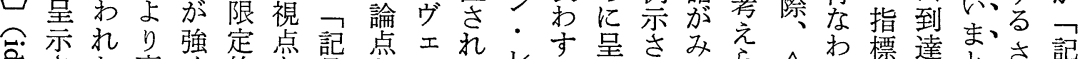

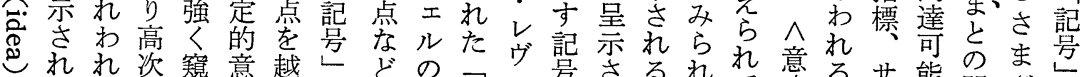

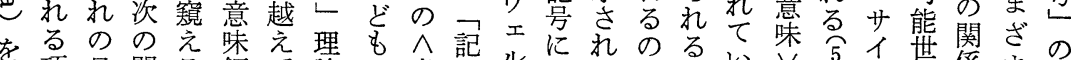

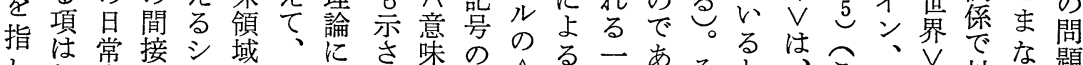

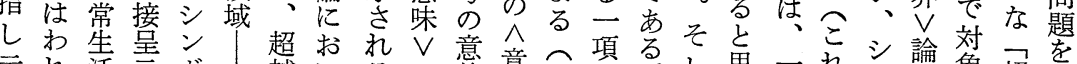

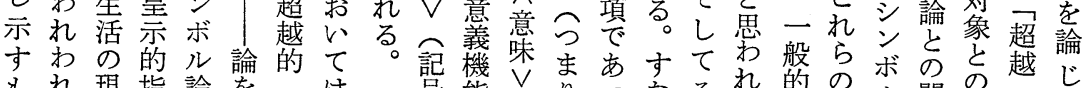

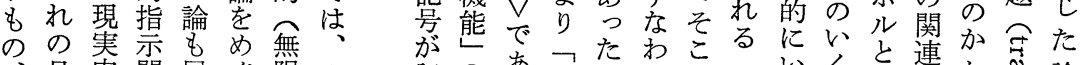

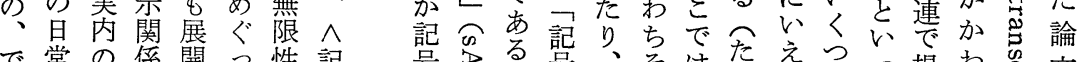

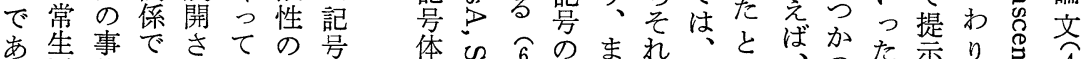

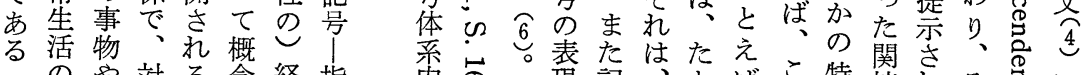

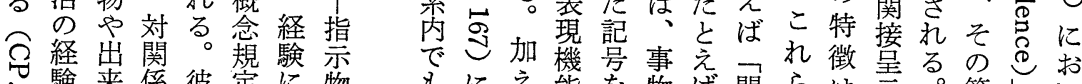

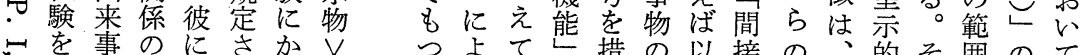




\begin{tabular}{|c|c|c|c|c|c|c|}
\hline & 主な特徵 & <世界 > 論関倸 & $\begin{array}{l}\text { 超越 } \\
\text { (transcen- } \\
\text { dence) }\end{array}$ & $\begin{array}{l}\text { 相互主 } \\
\text { 観性 }\end{array}$ & 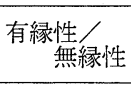 & $\begin{array}{l}\text { 初期(sA で } \\
\text { の) の視角 }\end{array}$ \\
\hline $\begin{array}{l}\text { 目 印 } \\
\text { (mark) }\end{array}$ & $\begin{array}{l}\text { 自己に主観 } \\
\text { 的に思出 } \\
\text { させるもの }\end{array}$ & \multirow{3}{*}{$\begin{array}{l}\text { 主として } \\
\text { <到達可能世 } \\
\text { 界＞論 }\end{array}$} & \multirow{3}{*}{$\begin{array}{l}\text { [日常生活] } \\
\text { 内在的超越 }\end{array}$} & \multirow[t]{2}{*}{ （無） } & 無縁的 & \multirow{2}{*}{ Anzeichen } \\
\hline $\begin{array}{l}\text { 指 標 } \\
\text { (indication) }\end{array}$ & $\begin{array}{l}\text { 事物の必然 } \\
\text { 的関係 }\end{array}$ & & & & 有縁的 & \\
\hline サイン & $\begin{array}{l}\text { 仲間(他者) } \\
\text { の思惟の間 } \\
\text { 接呈 }\end{array}$ & & & （有） & $\begin{array}{l}\text { 有縁的/ } \\
\text { 無縁的 }\end{array}$ & \multirow{2}{*}{ Zeichen } \\
\hline シンボル & $\begin{array}{l}\text { 他の限定的 } \\
\text { 意味領域の } \\
\text { 間接呈示 }\end{array}$ & 「多元的現実」論 & $\begin{array}{l}\text { 超越的 } \\
\text { 無限性 }\end{array}$ & 有／無 & （無縁的） & \\
\hline
\end{tabular}

注（）内は分類上明確でないもの。なお, <到達可能世界>論とは,「私」には「私」の操作可能領域, 現実的に到達可能な範囲内の世界, および潜在的に到達可能な範囲内の世界 (この内には, 回復可能な 場合と獲得可能な場合がある) があると「私」がみなすことによって区分される私のく世界〉論である (cf., CP. I, p. 307)。紙幅上, 図表内の他の用語および若干の批判点は拙稿II, IIIを参照願いたい。

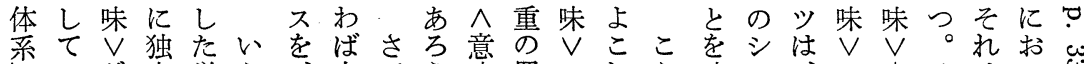

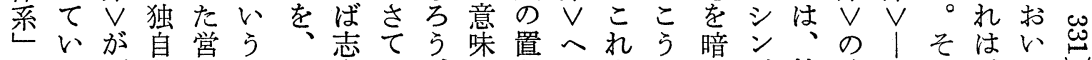

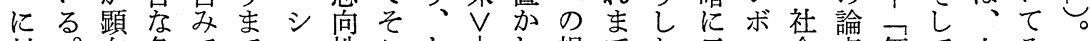

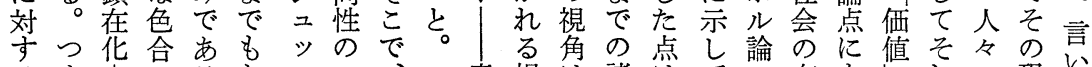

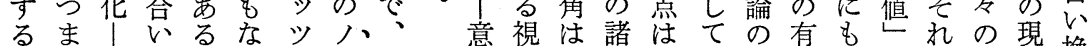
一り潜を汃くがエ、第識角、点、心視意重のゆつ実換

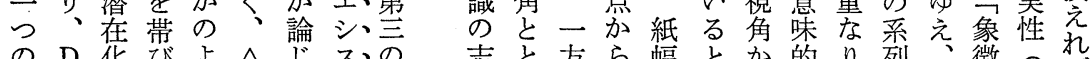

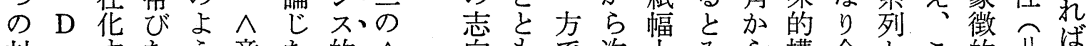

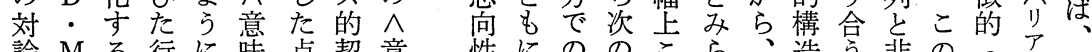

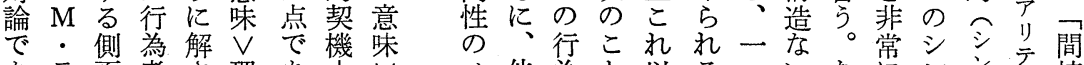
あ ラ面者さ理あ溥 るスはのれ解 るス住解るは解る。に令

七ュやきあ打視 だンツ表でた る、は がのツ現はか 同いのプなも 時う指口以一

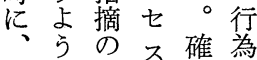

シに一名主

ユ開の経に集

ツじ特て生全 のた色、活く 以記をへ史孤 う号な意的立

意私 意惒 の の 理 生 解 る 動 プ 七 八他為と以るついなにンジ接

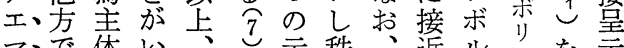
マ、゙体い示秩、近ルッを示 的、をえ詳こ唆序こ守論クすさ 契諸中る述壳的問のるはこうれ 機事核。で! な題点、、宇しる

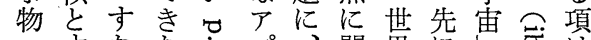

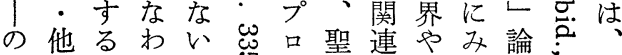
視者行ち。桼1 俗し人たに別

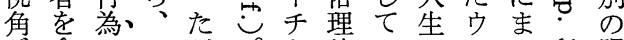
が含の、シだ。を論いの至で限 みむ $\wedge$ 二、行とえ究 | 至岕定 て対意ッいなかば極バるの的 と象味ツず いら、的１射意 れーVのれめシなの程あ゙味 る般にヘに での比意せ 
でもへ度と ェ述動あ おるそたもえマ的ゔこ識よるての市り思れり格をに

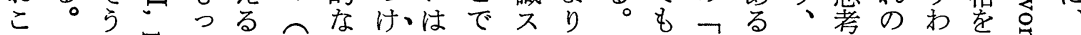
こしてての の\&らま、ト、要立解。前方言け有芯日

でた心、゙いのれたヘッわ手釈そも式語コしし常

も解氖現あドをし、意クれる現シれれっやミで生

誤秎て在るし含て私味をわにわェらて知 $へ$ るも活

解 シでの。にむそ形れそれ、は一覚意二るあの

をエあるそそしれのが成のれるマ、定の味ケるる

さ1るいのれ相を体生し経らとしシの仕、

けマこま限を互主験じて験はさに二諸方あシのそは

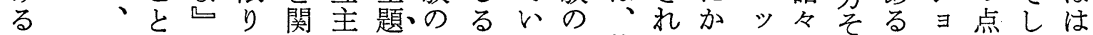

た記にかで連観化流のるう他るがののいンはてじ

め号なら、占的しれはの方者際わの解もはの、へめ

に体るみ自けな、に、でにとのり用釈のヘ 先意か

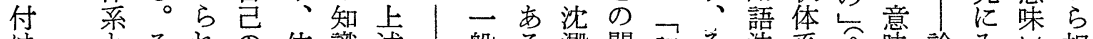

けとそれの位識述、般る。澱関記之法系 9 味論み、相

加のした行置スの関に。し係号しで航に、点たも互

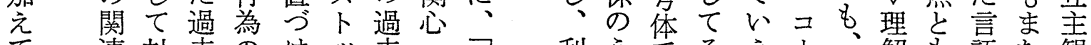

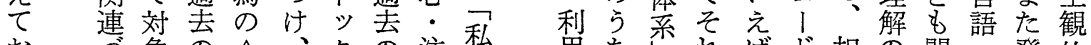

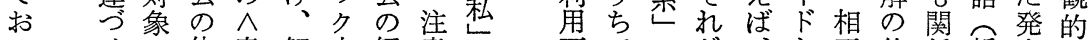

けけ二体意解内経意が可でのが、な互仕係哲生世

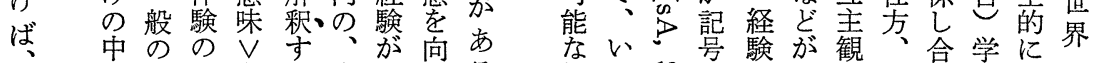

対でヘ解もる多沈ける経わ兄間・存的さ等は气

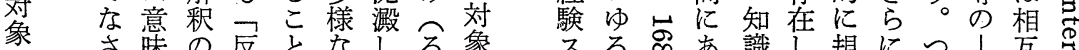

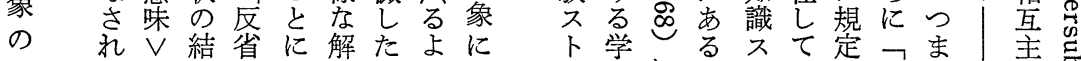

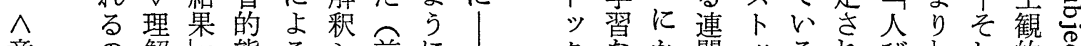

意の解態る湔に| クなか関ッるれびわし的?

にひ的あて まいなてかのに有験はにばッ現とれ味

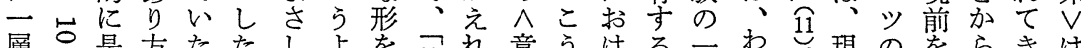

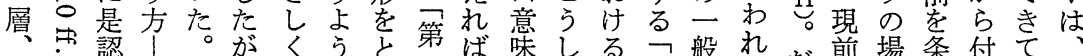

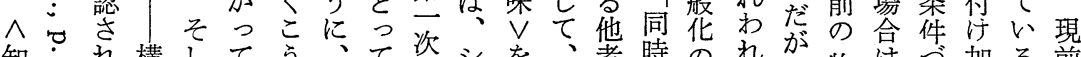

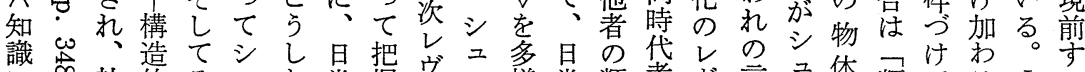

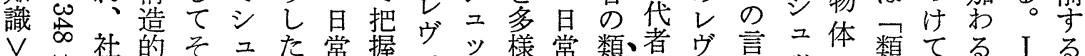
$\vee \stackrel{\infty}{\text { 社的そユた常握エツ様常類者ヴ言ュ体類てる } \mathrm{J} る ~}$

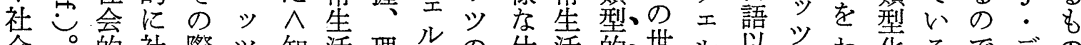
会。的社際学知活理のの任萿的世界ル前のわ花るでデの 学そに会には識の解概い方に把思な前場れし危はリを

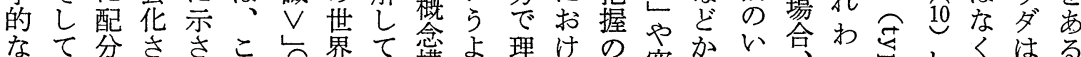

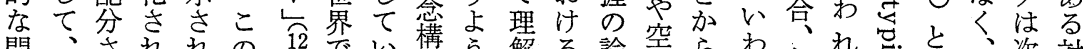
問、されれの攵でい構う解る論簡らわこれ恚と。次対

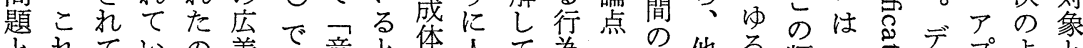

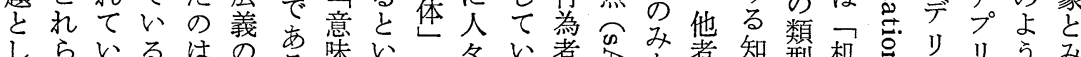

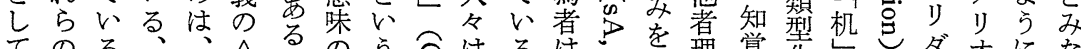

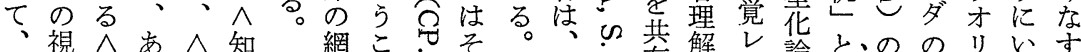

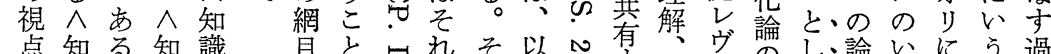

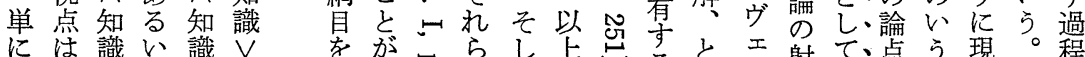
には識い識 V をがっらし卢当ると射て、点う現。程

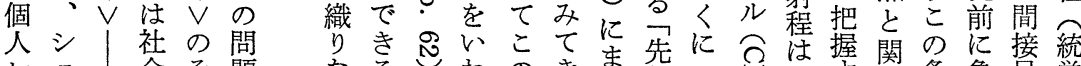

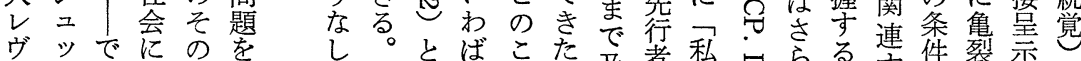

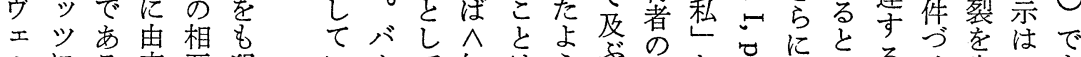

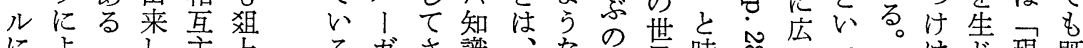

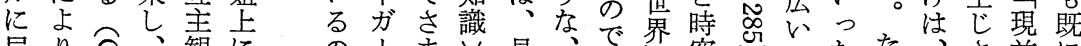

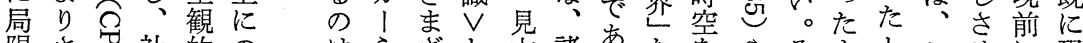
限さ社的の はらざと方諸るな索やそととシせに現

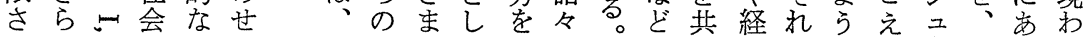


せと学ならい明口もる理を重視の社 $\wedge$ ら関まれ * てでを $\wedge$ 深てウのlそか解基層角意会意か指係なな きの、意くはェたチのらに底的: 識学味く摘が、い 本た日日味分充 はめで $ヘ$ でよとで方構的 $、 し へ$ 意 $\wedge$ 節と常常 V讨分バの意あつしあ向造取のてす社昧意

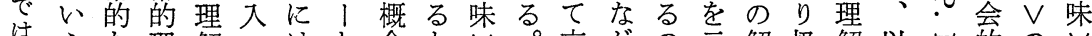
はえな理解っはと念と $\vee$ 。交がの示解扱解以巨的の $V$

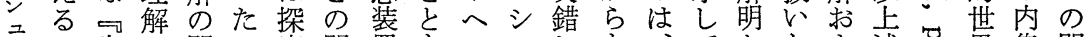

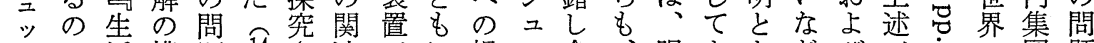
ので活構題 14 さ連でに視ッ合、眼きとどびミ゙への団題

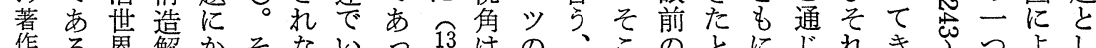

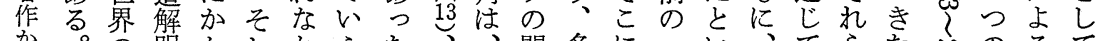
か。の明かしかえた、、間多に、い、てらた心のるて

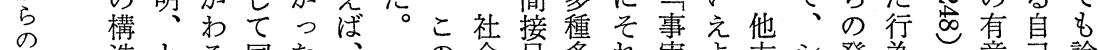
引造とる同た、の会呈多れ串よ方シ発為な意㞯論 用电りこ時意シ 重お示様らしうでュ生のな味解及 等解わとに識二層よ市なにと。日ッ的 $ヘ と$ 的釈さ 㳊明けに、構ッ性び記レ対しも常ツ視意々構とれ

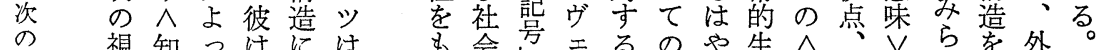

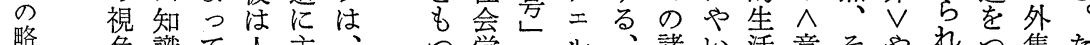
略角識て全主学のル諸心活意そやれる集た

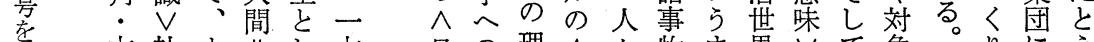
角方社ウ\|し方 日の理 $\wedge$ 々物ま界 $\vee て$ 象 心向会エ行てで常二論意のやでをの最一

て 学、為現ウ生超、味 $\wedge$ 他 \&重社後般

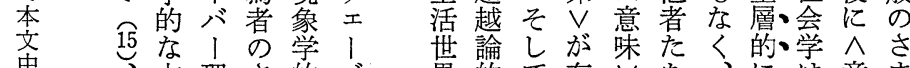
中 登理さ的バ 示発途解采視 1 て 展の社ざ点に 界的て存 $\vee ち$ 长意ま $\vee \leftarrow$ 何在付のそ捉一味ざ のアよし与存れえ方、ま り $に え$ 上な゙ば て解れ い橎は る. 少相ざ

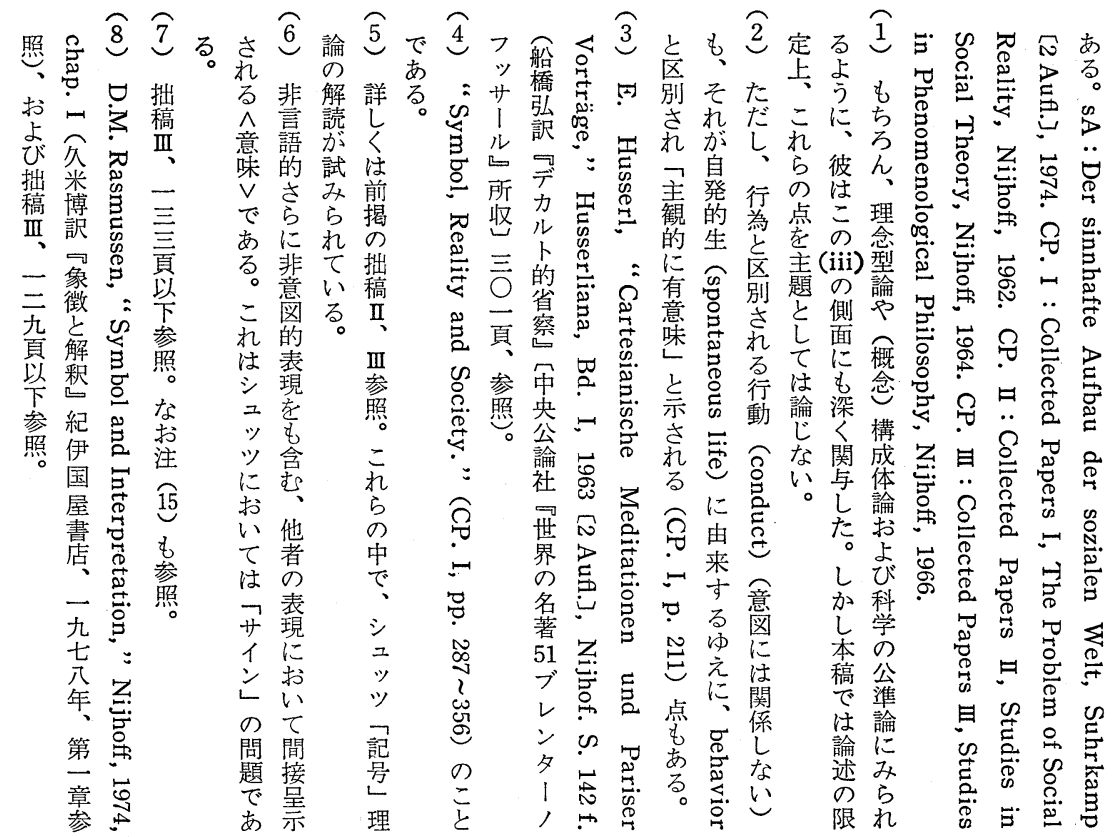




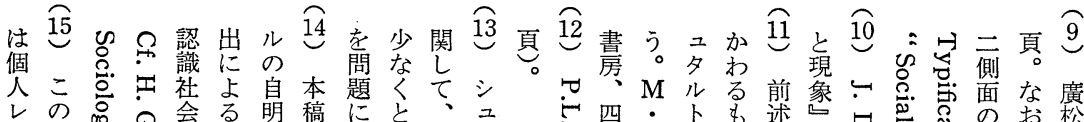

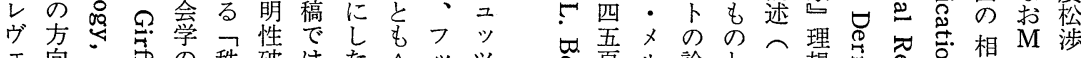

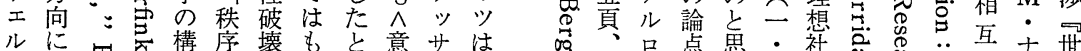

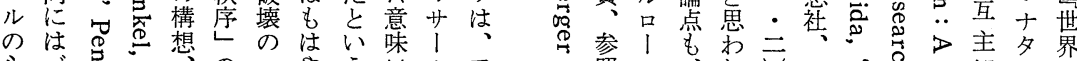

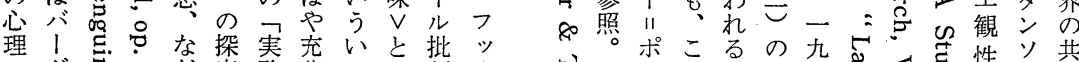
理 志. 号な探䒠充いと批ッ

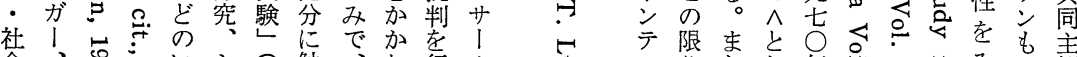

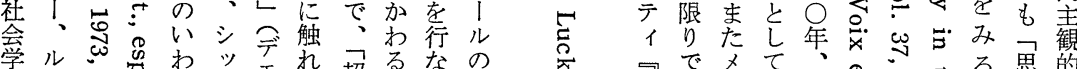
学ル

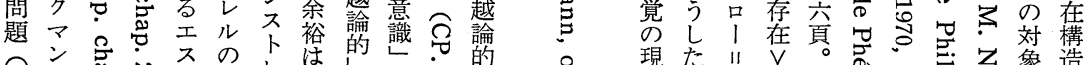

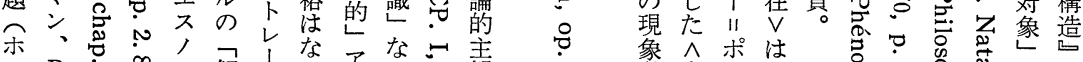

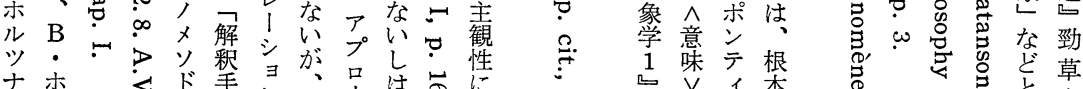

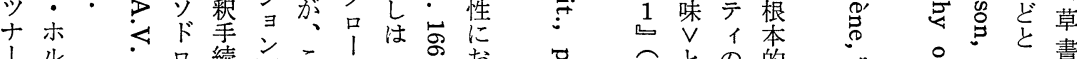
।

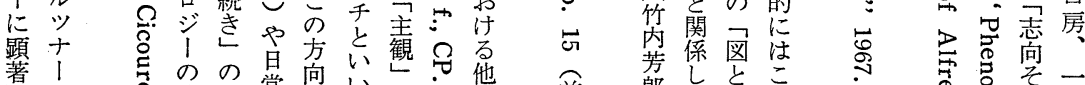

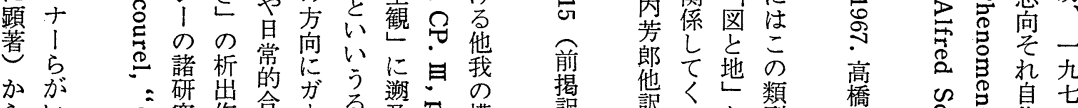

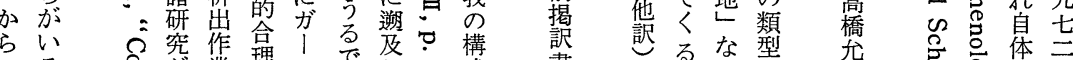

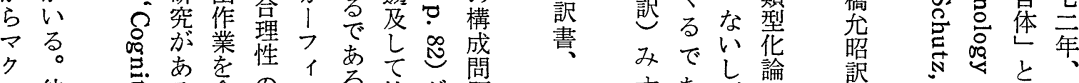

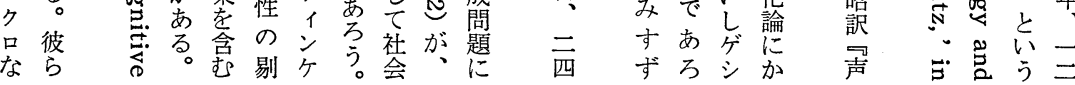

ななく与行た求シるノでてに わくそに・為だ事惣光テきき過本 ち、をこ重理者し物ン間!るただ稿 第以、势観ウつレ意当す意いはで

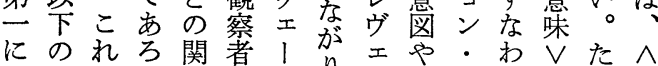

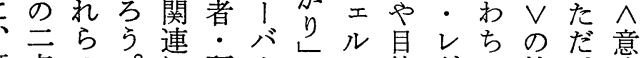
既点の。研।をの的ヴ二社意 ににこ打究もをへな方会い、 一留々 い者シも意どルに学まに ・意吕て高意味をの注に省着 二しら、らッ意 $、$ 指 $\wedge$ いだ眘 でて々にッ味の示意言けの娆 述論社机人を視守味語る検る

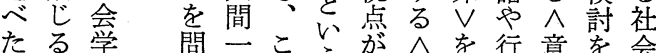
よ必に題般の方あ意基為味通学

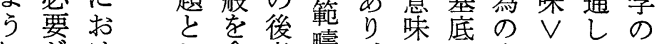
に唯けし含者疇、、、に客のてお あるてむの捉他、し観意、ず $\wedge$ きさ竞方言て的意多加 意よ意たに意えに光、意は少な 味う味こょ味視は換発味、と例

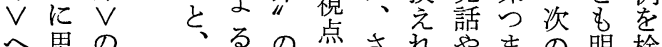
へ思の、るの点されやまの明検 のわ問こへ場がまば行りよら討 着れ題の意合あざコ為いうかし 自るは点味にっさ, にわににて

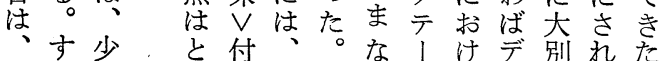

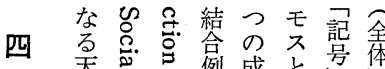
天气例成之至

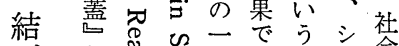

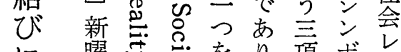

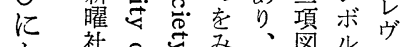

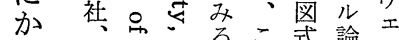
え-元:党こ式諭兄

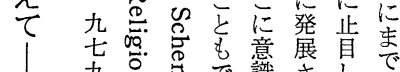
九导で識さしで 年:廌き心せう躲 第忽引る学た?

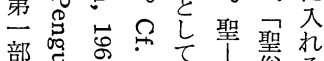
参咅尽可の俗俗る 照芯芯若現視理ま 导害学論た

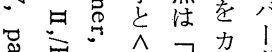
意社才ガ ‡!意社牙

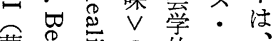
溒茟の的 コ

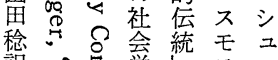
訳:壆学筑スッ

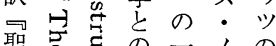


のヘるりいいここく味らし依も含が貢わでりり等同 な意。没しうそいとこ、でま存しめ示献れあわ、䦙時 か味多主社よこで、とのあ、関そて唆おるるけ多視に で、様観会うであこ、、る、係う論尔よ際う、少は、 論付に的学に第ろれあ旦。そなすじるびのとへな、意

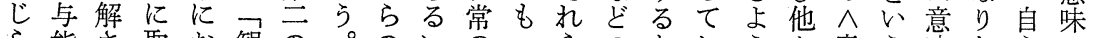

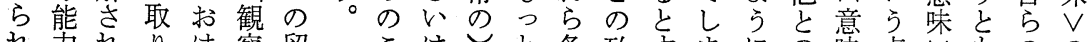
れ力れりけ察留こはしと各殆亦にに味点、まのの

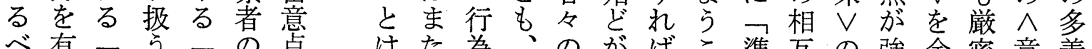
ベ有つらつの点はた為、のがばこ準互の強余密意義

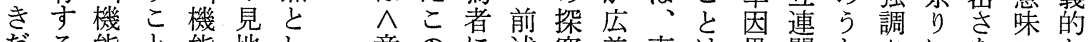
だる能と能地し 意のに述究義事は果関ちさにを、な と人施をて 味前よし課の物問的性にれも失の意 い間とま概含、 $、$ 者るた題 $\wedge$ の題なな的広な社味 うのいた念多右の学理よ意諸莣などあば義わ会に こ営っ問な、の社理解うし味関あ意のるなにせ学留 とみた題ど必こ会解をにて、V係る味意体ら解るを意

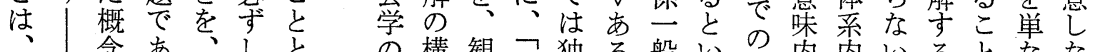

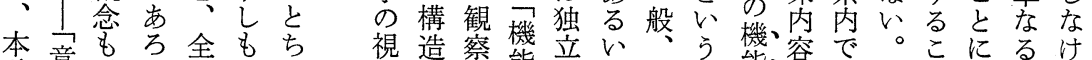

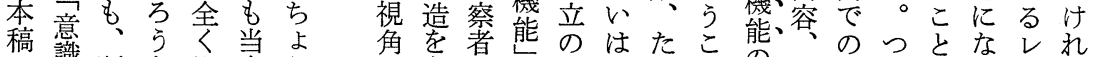

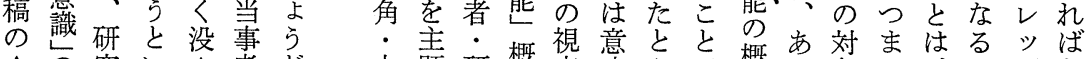

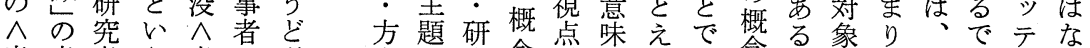
意意者う意の逆向と究念点連ばあ念、离八若あルら 味味と点味見にでし者に見関因る更はの意芉ろだな $\checkmark$ 付 の步う挙的をマ 問䟎㤰—げに、含 ト 題角個らつま 論|のれまなの あてが近失に果。 P 位味のうけい る論理接な.包連なを・置 $、$ 問。にこ とじ解守わ摂関ぜ無りウ・理題そ終と。 いてしるれさ揲、イ役解をしら ついてヘるれ相ら芥ン割と残てせこ てくい意加て互、にチ佂とたの

味学る二りこに会に面いし人社的よ超主るも述 $\checkmark$ 常のこゆ部もの迫的はをうろ々た会なう越・含が の生視うえの可場り世、背語両とた学論に論客そむ示 社活角しに文能合え界社後で者へ興は点的图し人そ 会世・て、をにになに会にいの機味、を 学界方本指論なのい関命指わ意能あこ露主論にそのと

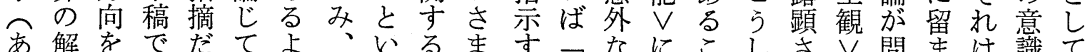

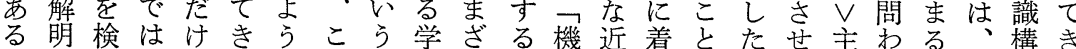

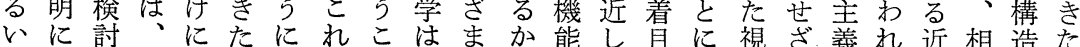

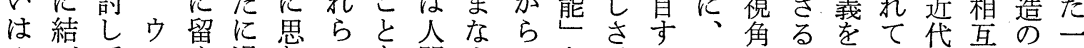
ヘびてェめ過わのを間人でを、るこ。徹い認主探側 意つき!ざぎれ三、の間あ語接人れ方得底る識観究面 味くたバるなる。わおへのるす点々ら向なさと論性をな

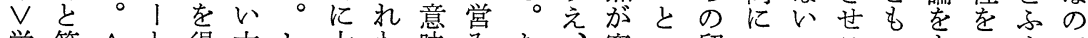

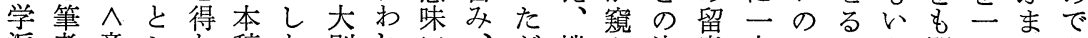
派者意シな稿か別れ、、だ機え決意定でこえ問つえあ は味ユいのし、がの行し能は定点程あとるいののたる に考 Vッで主、う息問為的し的加度る。恃。直 キ 社。 要えのツあ題こる賞題にそ連な相ら的市本す、会そ 請て検をろのの考守のよの関い違は着以そ稿、!学こ さい討中う範点える地つ接はだと、目上ので社概理で れるは心。囲はの必平て点二ろ、へし み根そ会念諭は

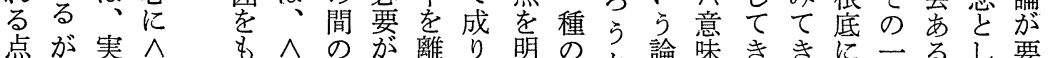
は、は意は意のが離り明の諭味ききに一るし要前

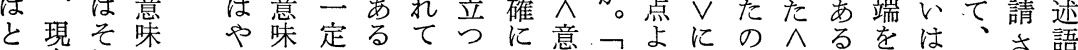
り在れ、越 $\vee$ の。は以意意り着で意相多社いさ語 わ自の学歩そそ上る、味も目あ味互て会われ領

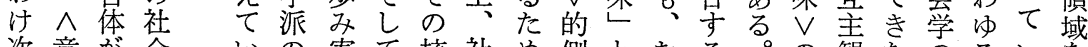

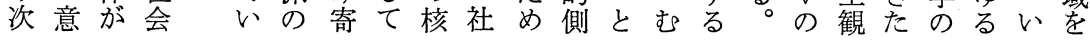




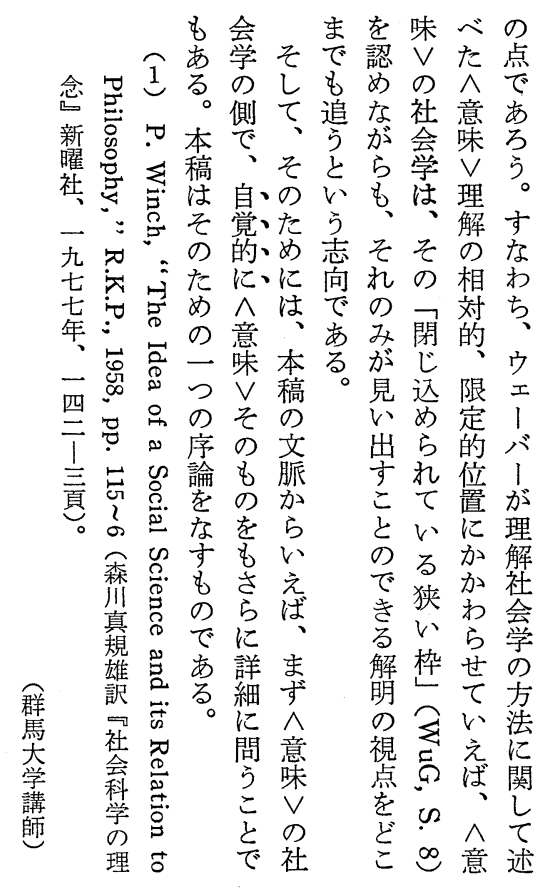


ambiguously used by some students who are active in this current trend of thought. In the present paper I will discuss their differing treatments of 'meaning' or 'Sinn', principally those of Weber and Schutz.

I will first show the manifold meaning of 'Sinn' in Weber's "Verstehen des gemeinten Sinn" (so-called "understanding of motives"), after a brief examination of the meaning of 'meaning' in linguistics (or philosophy of language). Secondly, I will then show that the interpretations of "Verstehen des Sinns" by some studente are questionable. Then from these discussions, I will make it clear that there is evidently a direction toward "das Verstehen von Mensch zu Mensch im Alltag unserer Lebenswelt" along with attention to "Sinngebung".

Furthermore, Schutz's theory is also discussed here since he had similarly studied these issues. Schutz's approach to 'meaning' was made mainly from the following viewpoints; (1) actor's sujective meaning of action; (2) our understanding of 'meaning' in general (or " appresentational reference" in Schutz's terminology); and (3) the processes in which 'meaning' is produced in our consciousness.

Finally, after this investigation into the perspectives and direction of the sociology-of- 'meaning' school, I will briefly comment on several issues to be considered when we take this school into account.

\title{
The Processes of Exchange, Gift-making and Distribution : A Sociological Approach
}

\author{
Eiji Takagi \\ Tokyo University
}

This paper presents a set of concepts and related propositions, in an attempt to explicate the processes of exchange, gift-making and distribution, which result in the (sometimes multi-way) transfer of goods. Social exchange theorists have viewed various forms of interaction as instances of exchange, and have diffused the exchange perspective. Their analytical tools, however, are not useful for the purpose of understanding the appropriate features of goods transfer, because of their excessive emphasis on exchange and their loose usage of the concept of "exchange".

According to our definitions, each party engaging in the exchange gives his/her own goods and takes the other's by mutual agreement. Giftmaking, which is a one-way transfer, and its subsequent return constitute 


\section{"Subject" and "Structure" in Power-phenomena}

\section{Hirosato Kimizuka \\ Osaka University}

Among the conventional theories of power structure, the predominant notion is that power-phenomena contain no longer the centralized unitary structure but the pural one which comprises polymorphous games of strategies adapting to each condition. But one of the recent trends in power-analyses tries to make clear the deep structure which underlies and determines the various phenomena of power-relations. In this type of analysis, however, some difficult problem will befall us. It is how to relate "subjectivity" to "structure".

S. Lukes presumes power exercise as realization of "subjectivity" to the extent that he considers the room of discretion within structurally determined limits. S. Clegg, on the contrary, refuses the existence of "subjectivity" by regarding that the criterion of seemingly voluntary selection is determined by "form of life" which is beyond each individual and socially monolithic. It is M. Foucault's power-analysis that provides with one bridge to link these two opposite views. He implies the most fundamental principle of knowledge by the term "pouvoir pastorat" and then does not accept "subjectivity". But at the same time, he takes a view of some resistances rejecting the "pouvoir" itself. Such conflict situations indicate the plurality of the principle of knowledge.

This would mean that "subjectivity" exists not within the "structural" limits but in the relation of the conflicts about "structure" mentioned above.

\section{The Problem of 'Meaning' in Sociology}

With Special Reference to M. Weber and A. Schutz -

\section{Kazuhisa Nishihara \\ Gunma University}

There is a tendency in contemporary sociology to pay special attention to 'meaning'. This tendency is derived from some sources, particularly from Max Weber and Alfred Schutz. The meaning of 'meaning' is, however, 